NBER WORKING PAPER SERIES

\title{
RACIAL AND ETHNIC DISPARITIES IN COVID-19: EVIDENCE FROM SIX LARGE CITIES
}

\author{
Joseph A. Benitez \\ Charles J. Courtemanche \\ Aaron Yelowitz \\ Working Paper 27592 \\ http://www.nber.org/papers/w27592 \\ NATIONAL BUREAU OF ECONOMIC RESEARCH \\ 1050 Massachusetts Avenue \\ Cambridge, MA 02138
}

July 2020

Yelowitz acknowledges support from University of Kentucky's Institute for the Study of Free Enterprise. We thank Chris Bollinger, Bill Hoyt, and James Ziliak for helpful comments. We thank SafeGraph for providing access to the data. The views expressed herein are those of the authors and do not necessarily reflect the views of the National Bureau of Economic Research.

NBER working papers are circulated for discussion and comment purposes. They have not been peer-reviewed or been subject to the review by the NBER Board of Directors that accompanies official NBER publications.

(C) 2020 by Joseph A. Benitez, Charles J. Courtemanche, and Aaron Yelowitz. All rights reserved. Short sections of text, not to exceed two paragraphs, may be quoted without explicit permission provided that full credit, including $\odot$ notice, is given to the source. 
Racial and Ethnic Disparities in COVID-19: Evidence from Six Large Cities

Joseph A. Benitez, Charles J. Courtemanche, and Aaron Yelowitz

NBER Working Paper No. 27592

July 2020

JEL No. I14

\begin{abstract}
$\underline{\text { ABSTRACT }}$
As of June 2020, the coronavirus pandemic has led to more than 2.3 million confirmed infections and 121 thousand fatalities in the United States, with starkly different incidence by race and ethnicity. Our study examines racial and ethnic disparities in confirmed COVID-19 cases across six diverse cities - Atlanta, Baltimore, Chicago, New York City, San Diego, and St. Louis - at the ZIP code level (covering 436 "neighborhoods" with a population of 17.7 million). Our analysis links these outcomes to six separate data sources to control for demographics; housing; socioeconomic status; occupation; transportation modes; health care access; long-run opportunity, as measured by income mobility and incarceration rates; human mobility; and underlying population health. We find that the proportions of black and Hispanic residents in a ZIP code are both positively and statistically significantly associated with COVID-19 cases per capita. The magnitudes are sizeable for both black and Hispanic, but even larger for Hispanic. Although some of these disparities can be explained by differences in long-run opportunity, human mobility, and demographics, most of the disparities remain unexplained even after including an extensive list of covariates related to possible mechanisms. For two cities - Chicago and New York - we also examine COVID-19 fatalities, finding that differences in confirmed COVID-19 cases explain the majority of the observed disparities in fatalities. In other words, the higher death toll of COVID-19 in predominantly black and Hispanic communities mostly reflects higher case rates, rather than higher fatality rates for confirmed cases.
\end{abstract}

Joseph A. Benitez

University of Kentucky

111 Washington Ave.

Lexington, KY 40508

joseph.benitez@uky.edu

Charles J. Courtemanche

Department of Economics

Gatton College of Business and Economics

University of Kentucky

Lexington, KY 40506-0034

and NBER

courtemanche@uky.edu
Aaron Yelowitz

University of Kentucky

Department of Economics

335 Business and Economics Building

Lexington, KY 40506-0034

aaron@uky.edu 


\section{Introduction}

By June 2020, the COVID-19 pandemic in the U.S. led to over 2.3 million confirmed infections, over 121,000 fatalities, and almost 31,000 hospitalizations (CDC 2020a,c). Like many other issues pertaining to health and economic disparities, the burden of the COVID-19 pandemic falls disproportionately on black and Hispanic communities. Through June 13, 2020, the rate of hospitalization for blacks and Hispanics was more than four times as high as for whites (CDC 2020b). The pandemic is taking a substantial toll on physical, mental, and economic health across the U.S., but disparities in whom is impacted by the virus are an additional cause for alarm.

Part of the barrier to carefully studying disparities from the pandemic - both their magnitudes and potential explanations - is that current published data on COVID-19 outcomes are coarse (Killeen et al. 2020). Most studies focus on COVID-19 outcomes at highly aggregated levels such as the state (Friedson et al. 2020) or county (Courtemanche et al. 2020). Within a state or county - especially in areas with larger populations - residential segregation by race and ethnicity can be quite stark, meaning that analyzing disparities at such levels misses an important part of the variation. Partway through the pandemic, a number of local and state governments began producing COVID-19 statistics in a more disaggregated fashion - most commonly reporting confirmed cases by ZIP code. This paper provides, to our knowledge, the first attempt to systematically investigate racial / ethnic disparities in COVID-19 using these newly available ZIP code level data. Specifically, we utilize data on confirmed COVID-19 cases from six cities - New York, Chicago, Atlanta, Baltimore, San Diego, and St. Louis - as well as data on fatalities from New York and Chicago. 
Our analysis links these COVID-19 outcomes to six separate data sources to control for ZIP code level demographics, housing, socioeconomic status, occupational choices, transportation modes, health care access, long-run opportunity (income mobility and incarceration rates), human mobility, and population health disparities. This rich set of covariates allows us to investigate the extent to which mechanisms that have received popular attention - such as income; education; living in densely-populated communities; reliance on public transportation; representation in forward-facing, essential jobs; mobility during lockdowns; pre-pandemic health; and access to health care - contribute to racial and ethnic disparities (Harrison 2020; Hubler et al. 2020; Oppel Jr. et al. 2020; CDC 2020b). We find statistically significant and economically meaningful disparities for both blacks and Hispanics at the ZIP code level in confirmed cases, and most of the disparity is remains unexplained even after including extensive controls. Without additional covariates, a 10 percentage point increase in a ZIP code's share of black residents is associated with 9.2 additional confirmed COVID-19 cases per 10,000 residents, while a similar change in the Hispanic share is associated with 20.6 additional cases. Both are sizable changes relative to the average confirmed case rate of 153 per 10,000 population. Using decompositions that are insensitive to the ordering of the covariates (Gelbach 2016), we find that at least part of these disparities can be explained by differences in long-run opportunity (income mobility and incarceration rates), human mobility as measured by cell-phone activity, and demographics. However, even with an extensive set of controls, more than half of the disparity in COVID-19 cases remains unexplained. For the two cities where we are also able to examine COVID-19 fatalities, we find that differences in confirmed COVID-19 cases strongly predict the observed disparities, in fact entirely eliminating 
the entire association for proportion Hispanic and the majority of the association for proportion black.

The remainder of the paper is arranged as follows. Section 2 examines the rapidly evolving COVID-19 literature with respect to disparities due to race and ethnicity. Section 3 discusses our data collection effort. Section 4 provides an empirical model and findings, and Section 5 concludes.

\section{Literature Review}

Despite growing recognition about racial and ethnic disparities in COVID-19, our study is, to our knowledge, the first to systematically investigate their size and possible explanations at a geographic level narrower than the county. Below we summarize the literature on racial disparities pertaining to COVID-19 infections, testing, and deaths, with the caveat that the literature is rapidly evolving. We then discuss, based on previous work, limitations on countylevel analyses and underlying mechanisms through which disparities could occur.

Nationwide, County-Level Analyses

Several recent studies utilize data on COVID-19 outcomes from U.S. counties and analyze racial and ethnic disparities. McLaren (2020) collects county-level data on COVID-19 mortality from the entire U.S. and links to county characteristics from the American Community Survey (ACS). By May 19, 2020, the unadjusted disparity shows a 10 percentage point increase in the black share corresponding to an increase of 37.6 additional fatalities per million, with a 10 percentage point increase in the Hispanic share associated with 9.6 additional fatalities. 
With additional controls - especially for public transit - the disparities decrease and in some cases become insignificant (suggesting potential mechanisms for the observed disparity). The study concludes that the disparity for blacks is very robust to the inclusion of additional covariates, although the one for Hispanics is more fragile.

Knittel and Ozaltun (2020) also examine COVID-19 death rates at the county-level and find mixed evidence of disparities. As of May 27, 2020, in a model with detailed controls but excluding state fixed effects, a 10 percentage point increase in the proportion black is associated with a large and statistically significant increase of 126.2 deaths per million residents. With state fixed effects included, the estimated disparity shrinks to a still sizeable 46.8 deaths per million but becomes statistically insignificant. The disparity for proportion Hispanic is not statistically significant in either model and the magnitudes are much smaller:

18.8 and 9.6 deaths per million in regressions without and with state fixed effects, respectively.

Desmet and Wacziarg (2020) examine both confirmed COVID-19 cases and fatalities. Outcomes are measured as logarithm of cases or fatalities (plus one) for May 26, 2020, where logarithm of population is included as a control, implying the other estimates can be interpreted as the determinants of cases and deaths in per capita terms. They find highly significant and virtually identical disparities in cases and fatalities for proportion black and somewhat smaller standardized coefficients for proportion Hispanic.

\section{Racial Segregation within U.S. Counties}

There is somewhat limited racial and ethnic variation across counties in the U.S., although the share of minority-majority counties has been increasing since 2000 (Krogstad 
2019). Fewer than 5 percent of all U.S. counties $(151$ out of 3,143) have either black, Hispanic, or indigenous people as the majority. As of 2018, there were 72 majority-black counties, primarily located in the southeastern U.S.; there were 69 counties where Hispanics are the majority, predominantly in the southwestern U.S. (Schaeffer 2019). Especially in large U.S. counties, there can be significant residential segregation, which may hide racial disparities in COVID-19 that can be more precisely measured at a more localized level. This limitation is wellunderstood; for example, McLaren (2020) notes "much of the relevant variation exists at the zip code level." On a national level, there are 658 counties that contain 10 or more residential ZIP codes entirely within the county. ${ }^{1}$ More than one-third of these counties have large dispersion - 25 percentage points or more - in the share black or Hispanic between the ZIP codes with the highest and lowest shares.

Neither the southeast or southwest regions were the initial hotspots for COVID-19 spread, raising the question of whether observed correlations between county racial composition and COVID-19 death rates are confounded by the staggered timing in which the disease reached different parts of the country. The sensitivity of the results of Knittel and Ozaltun (2020) to the inclusion of state fixed effects is suggestive of such confounding. Yet including state fixed effects in county-level disparities regressions could itself be problematic, as it controls away much of the identifying variation, reducing the precision of the estimates. Accordingly, their coefficient for proportion black becomes statistically insignificant after including state fixed effects despite remaining sizeable at 46.8 deaths per million. Estimating

\footnotetext{
${ }^{1}$ Calculations conducted with a crosswalk between ZIP codes and counties from the Missouri Census Data Center, along with information on racial and ethnic composition from Social Explorer.
} 
racial disparities with both credibility and precision therefore appears to require data with finer-grained geographic detail.

In our analysis of six cities, nearly $31 \%$ of ZIP codes we analyze were minority-majority "neighborhoods" (to borrow the terminology of Almagro and Orane-Hutchinson (2020), who refer to ZIP codes within New York City as neighborhoods). While analyses at even a more finely grained level than ZIP code (e.g. Census tract) would be more desirable, ZIP codes offer much more heterogeneity with respect to race and ethnicity than counties, while also having satisfactory indicators related to long-run economic opportunity, human mobility, and other key demographic and health-related information.

\section{Potential Explanations and Related Evidence}

Several factors may explain racial and ethnic disparities in the spread of COVID-19 and subsequent COVID-19 outcomes. We next explain these theories and associated empirical evidence. Many of the relevant studies examine New York City in isolation, since it was initially the hardest hit in the U.S., and because of its relatively early posting of ZIP code level data. Of course, New York City differs from the rest of the U.S. in many respects, even relative to other large cities, so the extent to which these findings are generalizable is unclear.

One possibility may be the nature of jobs. Many features about occupations, commuting, and the workplace could contribute to the spread of COVID-19, and may disproportionately affect people of color. Almagro and Orane-Hutchinson (2020) argue that occupation is a key explanatory variable for understanding the early transmission of COVID-19 in New York City, and since minority workers are more likely than others to be front-line 
employees or unable to work from home, they are more likely to be working outside the home during those hours. Accordingly, Coven and Gupta (2020) find that black and Hispanic neighborhoods (measured at the ZIP code level) in New York City exhibited more daytime work activity than other neighborhoods during the pandemic using mobile location data sourced from VenPath. Another phenomenon observed in New York City during the early stages of the pandemic was temporary relocation outside the city. Ability to relocate depends on whether one's job can be done remotely and also whether one has the financial resources to do so. Perhaps for these reasons, Coven and Gupta (2020) find that the propensity to leave the city was strongly negatively associated with the proportion black in the Census tract.

Health care access may also be an important factor, and the barriers to receiving COVID19 testing at the onset of the pandemic are well known. However, Schmitt-Grohé et al. (2020) found that testing services were evenly shared across the income distribution in New York City's 177 ZIP codes. Borjas (2020) finds access to testing was roughly uniform across the share of the ZIP code that was minority, but the conditional probability of a positive test result was far greater in neighborhoods with larger Black populations.

It is also possible that residential segregation as measured at the ZIP code level, and the consequences from it, led to long-lasting effects on health that made minority communities particularly vulnerable to COVID-19. Link and Phelan (1995) argue that social factors are a fundamental cause of disease that, because they embody access to important resources, affect multiple disease outcomes through multiple mechanisms, and consequently maintain an association with disease even when intervening mechanisms change. Phelan and Link (2015) argue that racial inequalities in health endure primarily because racism is a fundamental cause 
of racial differences in socioeconomic status, and in turn socioeconomic status is a fundamental cause of health inequalities. Chetty et al. (2019) find black Americans have much lower rates of upward mobility and higher rates of downward mobility than whites, leading to persistent disparities across generations. The black-white gap persists even among boys who grow up in the same neighborhood. Logan and Parman (2018) demonstrate that premature mortality among blacks is rooted in historical segregation. Using person-level data, the authors apply a comprehensive measure of segregation extending the analysis of structural factors in racial health disparities. Wiemers et al. (2020) highlight disparities in potential COVID-19 complications by constructing a vulnerability index from the Panel Study of Income Dynamics, finding that blacks are drastically more vulnerable than other groups among people aged 45 and older. National estimates find that COVID-19 related hospitalizations among blacks and Hispanics are more than 4 times that of whites (CDC 2020b). Price-Haywood et al. (2020) found that more than 70 percent of patients who were hospitalized or died of COVID-19 were black, compared to an overall population representation of 31 percent.

\section{3. $\underline{\text { Data }}$}

To analyze racial and ethnic disparities, we combine ZIP code level data on COVID-19 outcomes from state and local government websites with data from (1) the 2018 ACS 5-year sample, (2) the 2010 Census, (3) the Opportunity Atlas, (4) SafeGraph mobility data, (5) health professional shortage areas published by the Health Resources \& Services Administration, and (6) conditional life expectancy published by the Centers for Disease Control and Prevention. 
COVID-19 Data

From state and local websites, we gathered COVID-19 data at the ZIP code level for six metropolitan areas: New York City, Chicago, Atlanta, San Diego, St. Louis, and Baltimore. ${ }^{2}$ The ZIP codes include both the city proper, and in some cases the surrounding county. Crosssectional data was gathered from June 6, 2020 to June 9, 2020 for these localities. Once merged with all other sources, the full analysis uses 436 ZIP codes, with 177 in New York City, 58 in Chicago, 49 in Atlanta, 95 in San Diego, 21 in St. Louis, and 36 in Baltimore. Overall, there are approximately 17.7 million people living in these ZIP codes, with nearly half residing in New York City.

Our primarily outcome variable is confirmed COVID-19 cases per capita. Although serological surveys provide strong evidence that confirmed cases are an undercount of total infections, confirmed case numbers still have clear clinical and economic significance. Nationally, the fatality and hospitalization rates for confirmed cases were roughly $5 \%$ and $10 \%$, respectively, by June $2020 .{ }^{3}$ Even after discharge from a hospital, persistent symptoms may remain (Carfi et al. 2020). In addition, confirmed infections (which tend to be more severe that those that remain undetected) undoubtedly lead to lost earnings, family strain, psychological distress, and potentially harmful long-term consequences (Eisenberg et al. Forthcoming).

\footnotetext{
${ }^{2}$ The ZIP code data encompasses different geographies, based on what data was available. For New York City, there were initially 177 ZIP codes across all five boroughs. For Chicago, there were initially 60 ZIP codes for the city proper but our analysis does not include other parts of Cook County or DuPage County. For Atlanta, there were initially 59 ZIP codes within Fulton County. For San Diego, there were initially 100 ZIP codes within San Diego county. For St. Louis, there were initially 22 ZIP for the St. Louis City (and does not include St. Louis County). For Baltimore, there were initially 40 ZIP codes covering the city including parts of Baltimore City County, Baltimore County, and Anne Arundel County.

${ }^{3}$ University of Minnesota. COVID-19 Hospitalization Tracking Project. https://carlsonschool.umn.edu/mili-misrccovid19-tracking-project. Accessed June 16, 2020
} 
All six localities provided counts of COVID-19 cases, which are scaled into counts per 10,000 population. When weighted by population, Table 1 shows the median ZIP code had 143 cumulative cases per 10,000 population by early June, translating into a cumulative measured infection rate of about $1.4 \%$. Measured infection rates varied substantially, with 12 cases per $10,000(0.1 \%)$ in the lowest decile and 315 cases per $10,000(3.2 \%)$ in the highest decile. In the aggregate, New York City had the highest rate of confirmed cases (2.3\%), followed by Chicago (1.7\%) and Baltimore (0.9\%). The other three localities had confirmed case rates varying from $0.26 \%$ to $0.48 \%$. In the aggregate, there were more than 271,000 confirmed COVID-19 cases in these 6 cities, approximately $14 \%$ of all cases nationally by that point. ${ }^{4}$

We also conduct auxiliary analyses using a subsample of only Chicago and New York City, cities that provide additional data that allow us to investigate two important questions. First, do observed disparities in confirmed COVID-19 cases accurately reflect disparities in illnesses, or are they confounded by geographic variation in availability of tests and criteria for obtaining them? Note that we will include city fixed effects in all our models, which alleviates this concern to some extent. Nonetheless, since Chicago and New York City report tests run by ZIP code, they enable us to control for testing more directly. Second, are racial and ethnic disparities in COVID-19 fatalities the result of a higher likelihood of catching the virus, a greater risk of dying conditional on catching it, or some combination of both? Answering this question requires data on COVID-19 fatalities - not just cases - and Chicago and New York City are the only cities in our sample that report deaths by ZIP code. The bottom panel of Table 1 shows

\footnotetext{
${ }^{4}$ https://www.cdc.gov/coronavirus/2019-ncov/cases-updates/cases-in-us.html
} 
data for those two cities (and 235 ZIP codes). In these cities, the cumulative fatality rate from COVID-19 was $0.17 \%$ by early June.

\section{Census Bureau Data}

We merged this information to the 2018 ACS 5-year sample, as well as to the 2010 Decennial Census using Social Explorer (which provides summary statistics at the ZIP code level). The ACS contains a rich set of variables on demographics, economic outcomes, and housing characteristics. Demographic variables include percent male, percent foreign born, and percent aged $18-44,45-64,65-74$, and $75+$ (children under 18 are omitted). Housing variables include density, percent renters, percent vacant units, percent overcrowded (1.5 or more persons per bedroom), and percent of units with 0 or 1 bedrooms. The 2010 Census - although dated - provides information about group quarters, specifically percent of population in nursing homes, correctional facilities, college dormitories, and military barracks. Returning to the ACS 5-year sample, our socioeconomic variables include percent in education bins (dropout, high school, some college, bachelor's degree, the group beyond a bachelor's degree is omitted as a reference category), the Gini coefficient, and percent in poverty bins (0-49\% FPL, 50-74\%, 75$99 \%, 100-149 \%, 150-199 \%, 200 \%+$ is omitted). Occupation variables include percent of workers in service occupations, sales, farming, construction, production, or transport (managerial occupations omitted). Transportation variables include percent of workers of workers who use a car, percent who use public transportation, and percent with long commuting times (60+ minutes). Finally, one of our measures of health access - percent without health insurance comes from the ACS. 


\section{Opportunity Atlas Data}

The Opportunity Atlas is a collaboration of the Census Bureau, Harvard University, and Brown University that uses anonymous data following 20 million Americans from childhood to their mid-30s, with many outcomes measured at the Census tract level (which we aggregate up to ZIP code). As noted by Chetty et al. (2018), neighborhoods matter at a very granular level, where neighborhoods even one mile away have very little predictive power for child outcomes. We focus on two key variables, which represent long-run opportunity. The first is average annual household income ranking in 2014-2015 for children (in their mid-30s) who grew up in the area, based on having a low-income parent $\left(25^{\text {th }}\right.$ percentile). The second is fraction of male children who grew up in the area who were in prison or jail on April 1, 2010. We aggregate Census tracts to the ZIP code level using a crosswalk provided by the Missouri Census Data Center. We follow the spirit of Courtemanche et al. (2017) by assigning Census tract to the ZIP code where the plurality of residents live. In practice, approximately $53 \%$ of tracts nationally map into one ZIP code only, and roughly $75 \%$ of tracts have at least eighty percent of their population in one ZIP code.

\section{SafeGraph Data}

Many recent COVID-19 studies examine mobility using data from SafeGraph, which provides access to their data through free, non-commercial agreements. Following Gupta et al. (2020), we compute the fraction of cell phone devices that were detected to be entirely at home during the day, aggregating from the Census Block Group level to the ZIP code level. We aggregate Census Block Groups to ZIP codes using a crosswalk provided by the Missouri Census 
Data Center. We computed daily averages for each ZIP code, and then averaged across all days for the months of March 2020, April 2020, and May 2020. Again, following Courtemanche et al. (2017), we assign Census block groups to the ZIP code where the plurality of residents live. In practice, approximately $73 \%$ of block groups nationally map into one ZIP code only, and roughly $85 \%$ of tracts have at least eighty percent of their population in one ZIP code.

Health Professional Shortage Area Data

We incorporate information on each ZIP code's status as being designated as a health professional shortage area (HPSA) for federal fiscal year 2020. HPSAs are designated by the Health Resources and Services Administration (HRSA) to signify areas as medically underserved. The Centers for Medicare and Medicaid Services (CMS) provide HPSA designation status at the ZIP code level to signal to eligible health care professionals (e.g. physicians) if the location where they practice medical care is eligible for enhanced Medicare reimbursements per the 2005 Medicare Modernization Act (CMS 2020). This feature of the program creates a financial incentive for delivering care in medically underserved settings with historically higher uninsured rates and limited access to care. We use this as a proxy measure to capture differences in access to primary care and mental health services. HPSAs can be entire counties, but are most commonly smaller portions of a county-this is particularly the case in larger cities.

\section{Centers for Disease Control and Prevention Data}

Our population health variables are conditional life expectancies obtained from the U.S. Small-area Life Expectancy Estimates Project (USALEEP). The files contain conditional life expectancies for different age bins at the Census tract level; in our model, we include 
conditional life expectancies for ages $65-74,75-84$, and 85 plus, and aggregate from the tract level to ZIP code. Many commentators attribute disparities in COVID-19 cases and deaths to underlying health conditions such as elevated rates of chronic illnesses among blacks and Hispanics (Artiga et al. 2020). We use variation in life expectancy - and focus on the elderly who are most vulnerable to COVID-19 - to control for variation in underlying health status as well as the risk factors leading to differences in preventable mortality.

Table 2 shows, along some margins, large differences in neighborhood characteristics depending on racial and ethnic composition. Out of the 436 ZIP codes, 188 are majority white, 84 are majority black, 49 are majority Hispanic, and 115 are none of these. With respect to demographics, Hispanic neighborhoods have much higher representation of foreign-born individuals. With respect to housing, there are more renters in majority-black and majorityHispanic neighborhoods. Lower educational attainment and higher poverty levels are also common attributes of these neighborhoods, as are lower levels of income mobility - an indicator of long-run opportunity. At least some types of workers whose jobs do not easily transfer online - those in service occupations - are more prevalent in predominantly black and Hispanic neighborhoods. Also common in predominantly black and Hispanic neighborhoods are larger dependence on public transit as a key mode of transportation (McLaren 2020) and longer commuting times. Cell phone mobility measures are relatively similar, on average, across neighborhoods. Health care access is worse for black and Hispanic neighborhoods according to both percent uninsured and mental health HPSA, while population health - proxied by conditional life expectancy - is fairly similar across neighborhood types, especially from age 75 onward. Finally, racial composition and segregation varies by city. None of the ZIP codes in San 
Diego are majority Black, while Atlanta, Baltimore, and St. Louis have no ZIP codes that are majority Hispanic.

\section{Empirical Model and Findings}

Model

We estimate linear models of the following form:

$$
\operatorname{covid}_{z, j}=\beta_{0}+\beta_{1} P C T_{-} B L A C K_{z, j}+\beta_{2} P C T_{-} H_{I S P A N I C}, j+\beta_{3} O T H E R_{z, j}+\beta_{4} X_{z, j}+\delta_{j}+\varepsilon_{z, j}
$$

where $\operatorname{covid}_{z, j}$ represents either confirmed COVID-19 cases per 10,000 population or COVID-19 fatalities per $1,000,000$ population in ZIP code $z$ in city $j$. The key explanatory variables include the percentage black and percentage Hispanic in each ZIP code (we also include percentage Other race, with percentage white omitted). ${ }^{5}$ We successively include additional neighborhood characteristics in $X_{z, j}$. City fixed effects are given by $\delta_{j}$ and $\varepsilon_{z, j}$ is the error term. All observations are weighted by population in the ZIP code. Standard errors are heteroscedasticity-robust. ${ }^{6}$ Including city fixed effects controls for several important factors that do not vary within city, including the arrival of the virus, weather patterns, lockdown policies, and to some extent, the general availability of testing.

\footnotetext{
${ }^{5}$ In the subsequent tables, we focus attention on percent black and percent Hispanic. The Other race category includes several groups, some of which are not traditionally disadvantaged. Appendix Table 1 shows all the coefficients from our base model and full model.

${ }^{6}$ We also ran regressions clustering the standard errors at the city level, and this made the standard errors implausibly small in some cases. Since the number of clusters (6) is too small for cluster-robust inference to be reliable, we err on the side of caution and report the (larger) standard errors obtained without clustering. Also note that, since we do not include any city-level variables, there is no particular reason to think that standard errors obtained without clustering are systematically flawed (Cameron, Miller 2015).
} 
Any interpretation in an observational analysis like this identifies correlations, not causation (Knittel, Ozaltun 2020). With many observable neighborhood differences - including some characteristics that intuitively might represent greater likelihood of COVID-19 transmission such as density, occupations, modes of transport, or health care access - it may be tempting to attach causal stories. Our principal goal, however, is to assess the extent to which such measured characteristics can explain the disparities, and the extent to which disparities remain unexplained by conventional measures. Many neighborhood characteristics are likely correlated with race or ethnicity, and based on previous research, contribute to the spread of disease.

Size of Disparities

Our primary results are presented in Table 3, which examines confirmed COVID-19 infections per 10,000 population. In the top panel, we examine 436 ZIP codes across the 6 cities, and successively include covariates for demographics, housing, socioeconomic status, opportunity, occupation, transportation, human mobility, health access, and population health. The base model in column (1) - which only includes the race/ethnicity variables, city fixed effects and a constant term - shows large, highly significant health disparities for both blacks and Hispanics. A 10 percentage point increase in a ZIP code's black share is associated with to 9.2 additional confirmed COVID-19 cases per 10,000 population, while a similar change in the Hispanic share is associated with 20.6 additional COVID-19 cases. Both are very sizable changes relative to the average confirmed cases rate of 153 per 10,000 population. Across the remaining columns, the measured disparity remains sizable and significant, regardless of the set of controls that are included. The full model in column (10) shows disparities that are roughly 
60 percent as large as in column (1). Thus, a key insight is that even with an extensive set of controls for factors that should plausibly affect the transmission of the virus, more than half of the overall disparity in confirmed COVID-19 cases remains unexplained.

In the bottom panel, we focus on the 235 ZIP codes in Chicago and New York, since those localities provide additional data on COVID-19. The initial overall disparities in column (1) are larger, and a 10 percentage point increase in a ZIP code's black share is associated with 12.4 additional confirmed COVID-19 cases per 10,000 population, while a similar change in the Hispanic share is associated with to 24.8 additional COVID-19 cases. Again, both are sizable changes relative to the average confirmed cases rate of 219 per 10,000 population for these two cities. As neighborhood characteristics are added in the remaining columns, in some instances the disparity falls and in others it rises. With the full set of controls in column (10), there remain sizable disparities for both blacks and Hispanics, and again more than half of the overall disparity remains unexplained. It should be noted that the "health access" variables in column (9) now include COVID-19 tests per capita at the ZIP code level.

Next, we turn to Table 4, where we examine COVID-19 fatalities at the ZIP code level for Chicago and New York, an outcome that was a key focus in McLaren (2020) and Knittel and Ozaltun (2020). To maintain comparability, we scale COVID-19 fatalities per million population. In column (1), we estimate models with race / ethnicity controls, city fixed effects and a constant term, finding large and statistically significant disparities. A 10 percentage point increase in the black (Hispanic) share is associated with to 143 (149) additional fatalities per million, from a baseline of 1,727 per million in these two cities. In column (2), we include as an additional control COVID-19 cases (per 10,000) in each ZIP code. Thus, we ask the extent to 
which variation in fatalities is simply explained by greater numbers of confirmed COVID-19 cases, versus the extent to which factors beyond additional cases matter. The results show that the coefficients fall by $50-100 \%$, suggesting that racial and ethnic disparities in the spread of infection is an extremely important determinant for resultant fatalities. For proportion Hispanic, the coefficient estimate is very close to zero, while for proportion black, the coefficient estimate is about half as large. In columns (3) and onward, additional covariates similar to the ones in the bottom panel of Table 3 are added. With sufficient controls, the original racial and ethnic disparities become insignificant.

\section{Mechanisms}

In a highly cited paper, Gelbach (2016) shows that the sequence in which covariates are entered into the model can lead to very different conclusions about their relative importance. In our context, the extent to which different sets of neighborhood characteristics "explain" the observed racial and ethnic disparities may be sensitive to the sequence in which they are entered into the model. For example, the changes in racial and ethnic disparities from adding demographic covariates may have been different than those shown in Tables 3 and 4 if we had added housing variables first, since demographic and housing variables are correlated. In order to create a path-independent explanation of the influence of each set of neighborhood characteristics, Gelbach prescribes omitted variable bias equations. Essentially, we estimate omitted variable bias on the coefficient of interest from the exclusion of each sets of neighborhood controls one at a time from the full model (in Table 3, column 10). The influence of each set of neighborhood characteristics therefore becomes a function of the correlation 
between the covariate and race / ethnicity in addition to the covariate's coefficient in the full specification.

Table 5 shows the results of the Gelbach decomposition for our full set of 6 cities on COVID-19 cases (Table 3, top panel), as well for the 2 cities on cases and fatalities (Table 3 , bottom panel; Table 4). ${ }^{7}$ The baseline coefficient comes from the model that only includes racial / ethnic composition, city fixed effects, and a constant term. The "explained difference" is the reduction that occurs from moving from the first column to the last column (e.g., from 0.92 to 0.59 for "\% Black" in the top panel of Table 3), and the remaining rows show the contribution of each set of neighborhood characteristics to the explained reduction (as well as their statistical significance). In the model of COVID-19 cases with all 6 cities in column (1), much of the explained difference in the disparity for blacks can be attributed to the long run opportunity variables (income mobility and male incarceration rates for those born between 1978 and 1983). Although other sets of neighborhood characteristics occasionally have large magnitudes (e.g., the occupation controls), they are not statistically significant. For the Hispanic disparity, the opportunity variables again contribute to part of the explained difference; however, demographics (which includes the fraction foreign born) and human mobility (from SafeGraph) are larger factors.

The findings, when restricted to Chicago and New York, are somewhat different in for cases and fatalities (columns 2 and 3 of Table 5, respectively). For confirmed COVID-19 cases, the combined addition of all the covariates does little to change the estimate for proportion

\footnotetext{
${ }^{7}$ This was implemented with the "b1 $1 \times 2$ " command in Stata.
} 
black; however, several factors offset each other to result in essentially the zero change.

Controlling for health care access and human mobility is associated with statistically significant reductions in the disparity, but this is offset by statistically significant increases in the disparity from housing and socioeconomic characteristics and insignificant but similarly sized increases from occupation and transportation. For proportion Hispanic, the key driver explaining much of the reduction in confirmed cases appears to be health care access, which in the context of the two cities includes COVID-19 tests per capita. ${ }^{8}$

Finally, for COVID-19 fatalities (column 3 of Table5), adding covariates from the base model to the full model entirely explains the disparities for proportion black and Hispanic. The most important factor in explaining COVID-19 fatalities is simply the rate of infection.

Differences in confirmed cases explain approximately two-thirds of the disparity in fatalities for blacks, and the entire disparity for Hispanics. Other factors appear to have large and somewhat offsetting effects for both groups (e.g., socioeconomic controls and occupational controls), but a key implication is that understanding the core causes of COVID-19 cases can potentially explain the alarming subsequent differences in mortality.

\section{Robustness Checks}

We explore several robustness checks in Tables 6 and 7. As illustrated in Table 2, one key advantage of analyzing ZIP codes rather than counties is that residential segregation is much more stark. Overall, 327 of the 436 ZIP codes are highly segregated, and we re-estimate the models of COVID-19 cases restricted to neighborhoods that are the majority of one race or

\footnotetext{
${ }^{8}$ Appendix Table 1 shows that among health access variables for New York and Chicago, tests per capita is highly significant for confirmed cases.
} 
ethnicity in Table 6. Overall, the findings - both from the base model and full model - are very similar to Table 3. Next, our sample obviously differs from other county-level studies in that we include a small number of cities with far less aggregated data. We test the sensitivity of the results to excluding one city at a time in Table 7, presenting findings from the base specification and full specification. In all cases, there are sizable racial and ethnic disparities in the base specification. The findings on Hispanic disparities are robust across all specifications; there are large disparities that are partially explained by neighborhood characteristics. For proportion black, the baseline disparity was smaller than that for Hispanics, and the explained part was modest as well in Table 3.

\section{Conclusion}

In this study, we use ZIP code level data to understand the factors contributing to racial and ethnic disparities in COVID-19 burden. We find strong evidence that predominantly black and Hispanic neighborhoods were disproportionately at risk to COVID-19 infections and mortality although the disparities were larger among Hispanic neighborhoods. Even though our study was limited to six cities, these cities include the first (New York) and third (Chicago) largest in the U.S., and case counts from these cities accounted for 14 percent of all confirmed U.S. cases through June 9, 2020. The ZIP code level data allow us to examine a much wider range of variation in racial and ethnic composition than other studies using county-level data, and we also contribute to the literature by exploring numerous possible explanations for the disparities using decomposition methods. Differences in social mobility, demographics, and long-run 
opportunity arose as important contributors to COVID-related disparities. However, a significant share of the disparity in cases for blacks and Hispanics remains unexplained despite the inclusion of an exhaustive list of covariates. For fatalities, the majority of the disparities appear to be driven by the differences in cases, as opposed to differential case fatality rates. This is an important result, as it implies that interventions targeting reducing the spread of the virus in minority communities might be a more effective use of scarce resources than those targeting health care utilization once infected.

Our inability to explain most of the disparities in COVID-19 spread is perhaps surprising since we control for the risk factors largely associated with social deprivation. Recent studies have used area deprivation indexes (ADI) to explain disparities in avoidable hospitalizations and readmissions (Kind, Buckingham 2018; Jencks et al. 2019; Hu et al. 2018) and difficulty managing chronic illnesses (Kurani et al. 2020; Zhang et al. 2020; Camacho et al. 2017; Durfey et al. 2019). ADIs are composite measures generally made up of weighted combinations of education, labor market composition, income, income inequality, and housing market information such as home ownership (Singh 2003). Rather than use an ADI, we allow for each of our key covariates to enter into the regression separately, which is theoretically more flexible and should allow for greater explanatory power.

With that said, if our lengthy list of explanatory variables does not explain the disparities in COVID-19 cases, then what does? Are we not more successful in explaining the disparities because we are considering the wrong theories, or because available data are inadequate to fully test the existing theories? Structural racism may influence multiple mechanisms that are difficult to quantify (Poteat et al. 2020; Braveman, Gottlieb 2014). For example, racial biases 
could influence clinical decision making, which would not be captured by crude access

measures such as uninsured rates (Jones 2001). Obermeyer et al. (2019) found that several clinical decision-support algorithms were less likely to refer black patients for advanced care and screening than white patients presenting with identical symptoms. With respect to the COVID pandemic, there are reports of blacks being denied screenings after seeking care for COVID-19 symptoms at the early stages of this pandemic (Gathright 2020; Samuels 2020; Shamus 2020; Patton 2020; Mitropoulos, Moseley 2020). Additionally, perhaps conditional life expectancies are inadequate measures of underlying health risks. The premature deaths linked to COVID-19 complications are associated with poorer underlying health status and whether the person had a pre-existing condition such as diabetes, obesity, or hypertension, and we are unable to measure those directly. ${ }^{9}$ As another example, available socioeconomic information may not truly capture the source of disadvantage; percent with a high school or college degree says little about the quality of the schools attended, for instance.

To call the COVID-19 pandemic "the Great Equalizer" is a misnomer (Mein 2020; Kim et al. 2020), and the pandemic's key risk factors are unevenly distributed across communities. Even though we are able to explain some of the racial and ethnic disparities as attributable to different concentrations of socioeconomic risk factors, the fact that most of the case disparities remains unexplained demonstrates the difficulty of addressing deeply embedded racial and ethnic inequalities in health outcomes. Although more study is needed, our results suggest that

\footnotetext{
${ }^{9}$ The Centers for Disease Control and Prevention has several state and national level tools to monitor chronic diseases such as the Behavioral Risk Factor Surveillance System (BRFSS) and the National Health Interview Survey (NHIS), but the only publicly available resource at the county-level we are aware of is the U.S. Diabetes Surveillance System, and we are not aware of any at a narrower level than county.
} 
policies enacted to curb COVID-19's spread should consider how they would overcome the structural barriers to improvement across different groups. More superficial interventions such as economic stimulus or expanding health insurance coverage are unlikely to be fully adequate. 


\section{References}

Almagro M, Orane-Hutchinson A. The determinants of the differential exposure to COVID-19 in New York City and their evolution over time. Covid Economics. 2020;13.

Artiga S, Garfield R, Orgera K. Communities of Color at Higher Risk for Health and Economic Challenges Due to COVID-19. Kaiser Family Foundation. 2020. https://www.kff.org/coronaviruscovid-19/issue-brief/communities-of-color-at-higher-risk-for-health-and-economic-challengesdue-to-covid-19/. Accessed July 8, 20202020.

Borjas GJ. Demographic Determinants of Testing Incidence and COVID-19 Infections in New York City Neighborhoods. National Bureau of Economic Research Working Paper Series. 2020;No. 26952. doi:10.3386/w26952.

Braveman P, Gottlieb L. The Social Determinants of Health: Itś Time to Consider the Causes of the Causes. Public Health Reports. 2014;129(1suppl2):19-31.

Camacho FT, Tan X, Alcalá HE, Shah S, Anderson RT, Balkrishnan R. Impact of patient race and geographical factors on initiation and adherence to adjuvant endocrine therapy in medicare breast cancer survivors. Medicine. 2017;96(24):e7147-e.

Cameron AC, Miller DL. A Practitioner's Guide to Cluster-Robust Inference. The Journal of Human Resources. 2015;50(2):317-72. doi:10.3368/jhr.50.2.317.

Carfi A, Bernabei R, Landi F, Group ftGAC-P-ACS. Persistent Symptoms in Patients After Acute COVID-19. JAMA. 2020. doi:10.1001/jama.2020.12603.

CDC. Coronavirus Disease 2019 (COVID-19): Cases \& Deaths in the U.S. 2020a.

CDC. COVID-19 in Racial and Ethnic Minority Groups. Atlanta, GA2020b.

CDC. COVID-19 Laboratory-Confirmed Hospitalizations. 2020c.

Chetty R, Friedman JN, Hendren N, Jones MR, Porter SR. The Opportunity Atlas: Mapping the Childhood Roots of Social Mobility. National Bureau of Economic Research Working Paper Series. 2018;No. 25147. doi:10.3386/w25147.

Chetty R, Hendren N, Jones MR, Porter SR. Race and Economic Opportunity in the United States: an Intergenerational Perspective. The Quarterly Journal of Economics. 2019;135(2):71183. doi:10.1093/qje/qjz042.

CMS. Physician Health Professional Shortage Area Bonuses. 2020. https://www.cms.gov/Medicare/Medicare-Fee-for-ServicePayment/HPSAPSAPhysicianBonuses. Accessed July 8, 20202020. 
Courtemanche C, Garuccio J, Le A, Pinkston J, Yelowitz A. Strong Social Distancing Measures in the United States Reduced the COVID-19 Growth Rate. Health Affairs. 2020;39(7):1237-46. doi:https://doi.org/10.1377/hlthaff.2020.00608.

Courtemanche C, Marton J, Ukert B, Yelowitz A, Zapata D. Early Impacts of the Affordable Care Act on Health Insurance Coverage in Medicaid Expansion and Non-Expansion States. Journal of Policy Analysis and Management. 2017;36(1):178-210. doi:10.1002/pam.21961.

Coven J, Gupta A. Disparities in Mobility Responses to COVID-19. NYU Working Paper. 2020.

Desmet K, Wacziarg R. Understanding Spatial Variation in COVID-19 across the United States. National Bureau of Economic Research Working Paper Series. 2020;No. 27329. doi:10.3386/w27329.

Durfey SNM, Kind AJH, Buckingham WR, DuGoff EH, Trivedi AN. Neighborhood disadvantage and chronic disease management. Health services research. 2019;54 Suppl 1(Suppl 1):206-16.

Eisenberg MD, Barry CL, Schilling C, Kennedy-Hendricks A. Financial Risk for COVID-19-like Respiratory Hospitalizations in Consumer-Directed Health Plans. American Journal of Preventive Medicine. Forthcoming. doi:https://doi.org/10.1016/j.amepre.2020.05.008.

Friedson Al, McNichols D, Sabia JJ, Dave D. Did California's Shelter in Place Order Work? Early Evidence on Coronavirus-Related Health Benefits. National Bureau of Economic Research Working Paper Series. 2020;No. 26992. doi:10.3386/w26992.

Gathright J. D.C.ś Black Residents Make Up Less Than Half The Population, 80\% Of COVID-19 Deaths : NPR. 2020.

Gelbach JB. When Do Covariates Matter? And Which Ones, and How Much? Journal of Labor Economics. 2016;34(2):509-43. doi:10.1086/683668.

Gupta S, Nguyen TD, Rojas FL, Raman S, Lee B, Bento A et al. Tracking Public and Private Responses to the COVID-19 Epidemic: Evidence from State and Local Government Actions. National Bureau of Economic Research Working Paper Series. 2020;No. 27027. doi:10.3386/w27027.

Harrison D. Public Transit Use is Associated with Higher Coronavirus Death Rates, Researchers Find. The Wall Street Journal. 2020 June 28, 2020.

$\mathrm{Hu}$ J, Kind AJH, Nerenz D. Area Deprivation Index Predicts Readmission Risk at an Urban Teaching Hospital. American journal of medical quality : the official journal of the American College of Medical Quality. 2018;33(5):493-501. 
Hubler S, Fuller T, Singhvi A, Love J. Many Latinos Couldn't Stay Home. Now Virus Cases Are Soaring in Their Communities. The New York Times. 2020 June 26, 2020.

Jencks SF, Schuster A, Dougherty GB, Gerovich S, Brock JE, Kind AJH. Safety-Net Hospitals, Neighborhood Disadvantage, and Readmissions Under Marylandś All-Payer Program. Annals of Internal Medicine. 2019;171(2):91-8.

Jones CP. Invited Commentary: "Race," Racism, and the Practice of Epidemiology. American Journal of Epidemiology. 2001;154(4):299-304. doi:10.1093/aje/154.4.299.

Killeen BD, Wu JY, Shah K, Zapaishchykova A, Nikutta P, Tamhane A et al. A County-level Dataset for Informing the United States' Response to COVID-19. 2020.

Kim EJ, Marrast L, Conigliaro J. COVID-19: Magnifying the Effect of Health Disparities. Journal of General Internal Medicine. 2020:1-.

Kind AJH, Buckingham WR. Making Neighborhood-Disadvantage Metrics Accessible - The Neighborhood Atlas. The New England journal of medicine. 2018;378(26):2456-8.

Knittel CR, Ozaltun B. What does and does not correlate with COVID-19 death rates. medRxiv. 2020:2020.06.09.20126805. doi:10.1101/2020.06.09.20126805.

Krogstad JM. Reflecting a demographic shift, 109 U.S. counties have become majority nonwhite since 2000. Pew Research Center. 2019. https://www.pewresearch.org/facttank/2019/08/21/u-s-counties-majority-nonwhite/. Accessed July 3, 2020.

Kurani SS, McCoy RG, Lampman MA, Doubeni CA, Finney Rutten LJ, Inselman JW et al. Association of Neighborhood Measures of Social Determinants of Health With Breast, Cervical, and Colorectal Cancer Screening Rates in the US Midwest. JAMA network open. 2020;3(3):e200618-e.

Link BG, Phelan J. Social conditions as fundamental causes of disease. Journal of health and social behavior. 1995:80-94.

Logan TD, Parman JM. Segregation and mortality over time and space. Social Science \& Medicine. 2018;199:77-86. doi:https://doi.org/10.1016/j.socscimed.2017.07.006.

McLaren J. Racial Disparity in COVID-19 Deaths: Seeking Economic Roots with Census data2020.

Mein SA. COVID-19 and Health Disparities: the Reality of "the Great Equalizer". Journal of General Internal Medicine. 2020:1-.

Mitropoulos A, Moseley M. Beloved Brooklyn teacher, 30, dies of coronavirus after she was twice denied a COVID-19 test - ABC News. 2020. 
Obermeyer Z, Powers B, Vogeli C, Mullainathan S. Dissecting racial bias in an algorithm used to manage the health of populations. Science. 2019;366(6464):447-53.

doi:10.1126/science.aax2342.

Oppel Jr. RA, Gebeloff R, Lai KKR, Wright W, Smith M. The Fullest Look Yet at the Racial Inequity of Coronavirus. The New York Times. 2020 July 5, 2020.

Patton S. Black America is suffering from the coronavirus - The Washington Post. 2020.

Phelan JC, Link BG. Is racism a fundamental cause of inequalities in health? Annual Review of Sociology. 2015;41:311-30.

Poteat T, Millett GA, Nelson LE, Beyrer C. Understanding COVID-19 risks and vulnerabilities among black communities in America: the lethal force of syndemics. Annals of Epidemiology. 2020;47:1-3.

Price-Haywood EG, Burton J, Fort D, Seoane L. Hospitalization and Mortality among Black Patients and White Patients with Covid-19. New England Journal of Medicine. 2020. doi:10.1056/nejmsa2011686.

Samuels A. Black Texans already face health care disparities: The coronavirus is making it worse. 2020.

Schaeffer K. Rising Number of U.S. Counties Are Majority Hispanic or Black. Pew Research Center. 2019. https://www.pewresearch.org/fact-tank/2019/11/20/in-a-rising-number-of-u-scounties-hispanic-and-black-americans-are-the-majority/. Accessed July 3, 2020.

Schmitt-Grohé S, Teoh K, Uribe M. Covid-19: Testing Inequality in New York City. National Bureau of Economic Research Working Paper Series. 2020;No. 27019. doi:10.3386/w27019.

Shamus KJ. Family ravaged by coronavirus begged for tests, hospital care but was repeatedly denied. 2020.

Singh GK. Area deprivation and widening inequalities in US mortality, 1969-1998. American journal of public health. 2003;93(7):1137-43.

Wiemers EE, Abrahams S, AlFakhri M, Hotz VJ, Schoeni RF, Seltzer JA. Disparities in Vulnerability to Severe Complications from COVID-19 in the United States2020.

Zhang Y, Ancker JS, Hall J, Khullar D, Wu Y, Kaushal R. Association Between Residential Neighborhood Social Conditions and Health Care Utilization and Costs. Medical care. 2020;58(7):586-93. 


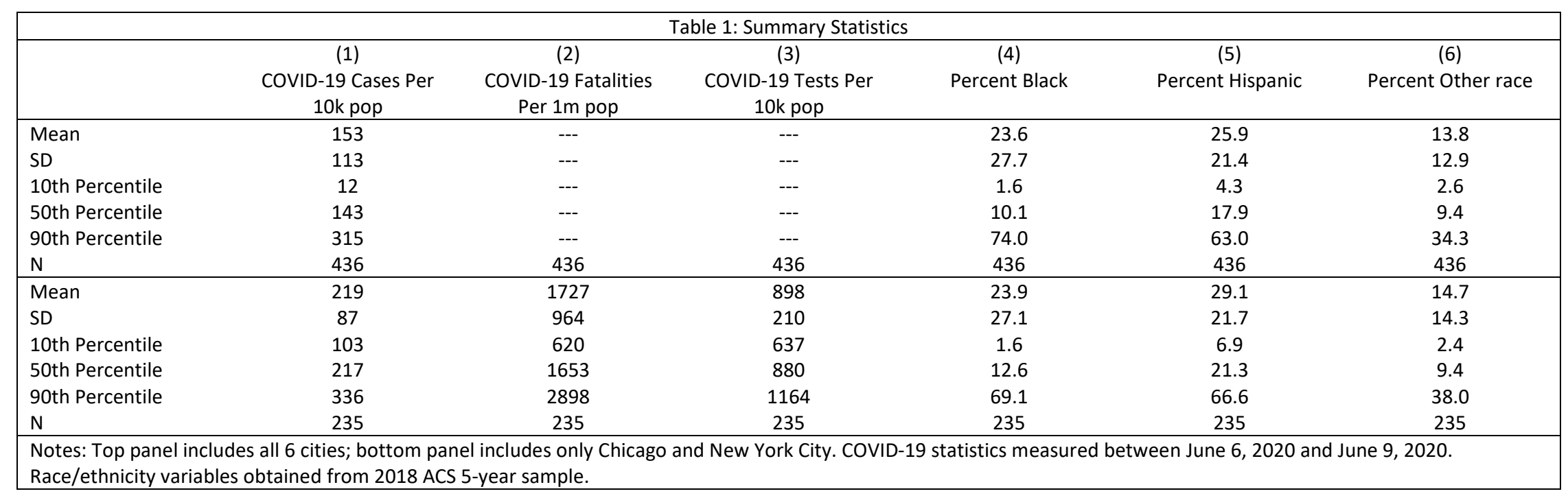




\begin{tabular}{|c|c|c|c|c|}
\hline & Majority White & Majority Black & Majority Hispanic & All Other ZIPs \\
\hline \multirow[t]{2}{*}{ Confirmed COVID-19 case per 10k pop } & 99.9 & 171.7 & 237.4 & 161.9 \\
\hline & (6.6) & $(11.1)$ & $(16.7)$ & $(10.3)$ \\
\hline \multirow[t]{2}{*}{$\%$ White } & 64.9 & 10.3 & 12.7 & 31.4 \\
\hline & $(0.7)$ & (1.1) & $(1.6)$ & $(1.4)$ \\
\hline \multirow[t]{2}{*}{$\%$ Black } & 7.0 & 74.6 & 15.2 & 15.9 \\
\hline & $(0.5)$ & $(1.6)$ & $(1.6)$ & $(1.4)$ \\
\hline \multirow[t]{2}{*}{ \% Hispanic } & 14.3 & 10.5 & 64.7 & 28.4 \\
\hline & $(0.6)$ & $(1.2)$ & $(1.3)$ & $(1.3)$ \\
\hline \multirow[t]{2}{*}{$\%$ Other } & 13.8 & 4.6 & 7.4 & 24.3 \\
\hline & $(0.5)$ & $(0.4)$ & $(0.8)$ & $(1.7)$ \\
\hline \multicolumn{5}{|l|}{ Demographic controls } \\
\hline \multirow[t]{2}{*}{$\%$ Age $18-44$} & 41.5 & 38.6 & 41.4 & 41.2 \\
\hline & $(0.8)$ & $(0.6)$ & $(0.5)$ & $(0.6)$ \\
\hline \multirow[t]{2}{*}{$\%$ Age $45-64$} & 24.7 & 25.0 & 22.7 & 24.6 \\
\hline & $(0.3)$ & $(0.3)$ & $(0.3)$ & $(0.3)$ \\
\hline \multirow[t]{2}{*}{$\%$ Age $65-74$} & 8.3 & 7.7 & 6.3 & 7.3 \\
\hline & $(0.2)$ & $(0.2)$ & $(0.2)$ & $(0.2)$ \\
\hline \multirow[t]{2}{*}{$\%$ Age $75+$} & 6.4 & 5.8 & 4.5 & 5.6 \\
\hline & $(0.2)$ & $(0.2)$ & $(0.2)$ & $(0.2)$ \\
\hline \multirow[t]{2}{*}{$\%$ Foreign-born } & 21.8 & 18.7 & 37.3 & 34.9 \\
\hline & $(0.8)$ & $(1.8)$ & $(1.3)$ & $(1.4)$ \\
\hline \multirow[t]{2}{*}{$\%$ Male } & 48.8 & 45.7 & 49.2 & 49.0 \\
\hline & $(0.2)$ & $(0.3)$ & $(0.3)$ & $(0.2)$ \\
\hline \multicolumn{5}{|l|}{ Housing controls } \\
\hline \multirow[t]{2}{*}{ Density } & 25835 & 22888 & 40125 & 25712.6 \\
\hline & $(2448)$ & $(2685)$ & (4724) & $(2103.1)$ \\
\hline \multirow[t]{2}{*}{$\%$ College group quarters } & 1.0 & 0.6 & 0.1 & 0.7 \\
\hline & $(0.2)$ & $(0.3)$ & $(0.1)$ & $(0.3)$ \\
\hline \multirow[t]{2}{*}{$\%$ Correctional group quarters } & 0.2 & 0.5 & 0.6 & 0.3 \\
\hline & $(0.1)$ & $(0.3)$ & $(0.3)$ & $(0.2)$ \\
\hline \multirow[t]{2}{*}{$\%$ Military group quarters } & 0.3 & 0.0 & 0.4 & 0.1 \\
\hline & $(0.3)$ & $(0.0)$ & $(0.3)$ & $(0.1)$ \\
\hline \multirow[t]{2}{*}{$\%$ Nursing home group quarters } & 0.5 & 0.5 & 0.4 & 0.5 \\
\hline & $(0.0)$ & $(0.1)$ & $(0.1)$ & $(0.1)$ \\
\hline \multirow[t]{2}{*}{$\%$ Unit is 0 or 1 bedroom } & 28.2 & 22.0 & 28.6 & 25.2 \\
\hline & (1.4) & $(1.3)$ & $(2.1)$ & $(1.4)$ \\
\hline \multirow[t]{2}{*}{$\% 1.5+$ Occupants per bedroom } & 1.8 & 1.5 & 4.7 & 2.8 \\
\hline & $(0.1)$ & $(0.1)$ & $(0.4)$ & $(0.2)$ \\
\hline$\%$ Renter & 49.6 & 59.5 & 71.4 & 56.9 \\
\hline & (1.4) & (1.9) & (2.9) & $(1.7)$ \\
\hline$\%$ Vacant & 9.3 & 14.0 & 7.2 & 8.1 \\
\hline & $(0.4)$ & $(0.9)$ & $(0.5)$ & $(0.3)$ \\
\hline Socio-economic & & & & \\
\hline Gini coefficient & 47.5 & 48.2 & 46.2 & 46.2 \\
\hline & $(0.4)$ & $(0.6)$ & $(0.6)$ & $(0.5)$ \\
\hline \% HS Dropout & 8.6 & 15.8 & 30.0 & 17.5 \\
\hline & $(0.5)$ & $(0.5)$ & $(0.9)$ & $(0.7)$ \\
\hline \% HS Graduate/GED & 17.0 & 30.2 & 27.5 & 23.9 \\
\hline & $(0.7)$ & $(0.6)$ & $(0.8)$ & $(0.7)$ \\
\hline \% Some College & 20.9 & 28.8 & 23.9 & 23.5 \\
\hline & $(0.6)$ & $(0.5)$ & $(0.7)$ & $(0.6)$ \\
\hline \% Bachelor's degree & 30.0 & 15.3 & 12.6 & 21.8 \\
\hline & $(0.7)$ & $(0.6)$ & $(0.7)$ & $(0.6)$ \\
\hline
\end{tabular}




\begin{tabular}{|c|c|c|c|c|}
\hline$\% 0-49 \mathrm{FPL}$ & $\begin{array}{c}5.5 \\
(0.2)\end{array}$ & $\begin{array}{l}11.1 \\
(0.6)\end{array}$ & $\begin{array}{l}10.1 \\
(0.7)\end{array}$ & $\begin{array}{c}7.5 \\
(0.4)\end{array}$ \\
\hline \multirow[t]{2}{*}{$\%$ 50-74 FPL } & 2.7 & 5.8 & 7.0 & 4.0 \\
\hline & $(0.2)$ & $(0.3)$ & $(0.4)$ & $(0.2)$ \\
\hline \multirow[t]{2}{*}{$\% 75-99$ FPL } & 3.5 & 6.1 & 7.8 & 5.1 \\
\hline & $(0.2)$ & $(0.2)$ & $(0.3)$ & $(0.2)$ \\
\hline \multirow[t]{2}{*}{$\%$ 100-149 FPL } & 6.3 & 11.0 & 14.0 & 10.0 \\
\hline & $(0.2)$ & $(0.3)$ & $(0.4)$ & $(0.3)$ \\
\hline \multirow[t]{2}{*}{ \% 150-199 FPL } & 6.1 & 10.1 & 12.1 & 9.1 \\
\hline & $(0.2)$ & $(0.2)$ & $(0.3)$ & $(0.2)$ \\
\hline \multicolumn{5}{|l|}{ Opportunity Atlas controls } \\
\hline \multirow[t]{2}{*}{ Income mobility } & 44.7 & 33.7 & 39.6 & 44.0 \\
\hline & $(0.5)$ & $(0.5)$ & $(0.5)$ & $(0.7)$ \\
\hline \multirow[t]{2}{*}{ Male incarceration } & 2.9 & 8.3 & 3.5 & 3.0 \\
\hline & $(0.2)$ & $(0.4)$ & $(0.3)$ & $(0.2)$ \\
\hline \multicolumn{5}{|l|}{ Occupational controls } \\
\hline \multirow[t]{2}{*}{ \% Sales Occupation } & 20.9 & 22.4 & 21.0 & 21.6 \\
\hline & $(0.2)$ & $(0.3)$ & $(0.4)$ & $(0.2)$ \\
\hline \multirow[t]{2}{*}{ \% Service } & 14.3 & 26.4 & 30.9 & 22.1 \\
\hline & $(0.4)$ & $(0.6)$ & $(1.0)$ & $(0.5)$ \\
\hline \multirow[t]{2}{*}{$\%$ Construction } & 4.8 & 5.3 & 9.0 & 6.8 \\
\hline & $(0.3)$ & $(0.2)$ & $(0.5)$ & $(0.3)$ \\
\hline \multirow[t]{2}{*}{ \% Transport } & 4.4 & 10.3 & 10.1 & 7.2 \\
\hline & $(0.2)$ & $(0.3)$ & $(0.4)$ & $(0.3)$ \\
\hline \multirow[t]{2}{*}{$\%$ Production } & 2.4 & 3.2 & 5.7 & 3.6 \\
\hline & $(0.1)$ & $(0.2)$ & $(0.5)$ & $(0.2)$ \\
\hline \multirow[t]{2}{*}{$\%$ Farming } & 0.1 & 0.1 & 0.3 & 0.2 \\
\hline & $(0.0)$ & $(0.0)$ & $(0.1)$ & $(0.0)$ \\
\hline \multicolumn{5}{|l|}{ Transportation controls } \\
\hline \multirow[t]{2}{*}{$\%$ Travel by car } & 56.9 & 53.2 & 46.2 & 51.7 \\
\hline & (2.3) & (2.5) & (4.4) & $(2.6)$ \\
\hline \multirow[t]{2}{*}{$\%$ Travel by public transit } & 26.1 & 37.5 & 42.5 & 36.4 \\
\hline & (1.8) & (2.4) & $(4)$ & $(2.4)$ \\
\hline \multirow[t]{2}{*}{$\% 60+$ minute commute } & 12.6 & 23.1 & 22.4 & 20.2 \\
\hline & $(0.8)$ & $(1.2)$ & $(1.5)$ & $(1.1)$ \\
\hline SafeGraph mobility controls & & & & \\
\hline$\%$ Home all day, 3/2020 & 33.8 & 35.1 & 37.3 & 37.2 \\
\hline & $(0.3)$ & $(0.4)$ & $(0.5)$ & $(0.4)$ \\
\hline$\%$ Home all day, 4/2020 & 47.4 & 46.9 & 51.0 & 53.2 \\
\hline & $(0.5)$ & $(0.7)$ & (0.9) & (0.7) \\
\hline$\%$ Home all day, 5/2020 & 43.8 & 43.3 & 45.9 & 48.6 \\
\hline & $(0.5)$ & $(0.6)$ & $(0.8)$ & $(0.7)$ \\
\hline Health access controls & & & & \\
\hline$\%$ Uninsured & 6.2 & 9.8 & 13.4 & 10.0 \\
\hline & $(0.2)$ & $(0.4)$ & $(0.6)$ & $(0.4)$ \\
\hline Mental health HPSA & 0.9 & 13.8 & 12.4 & 1.0 \\
\hline & $(0.7)$ & (3.8) & $(4.8)$ & $(0.9)$ \\
\hline Primary care HPSA & 0.0 & 4.7 & 0.0 & 1.0 \\
\hline & $(0.1)$ & $(2.3)$ & $(0.3)$ & $(0.9)$ \\
\hline Population health controls & & & & \\
\hline Life Expectancy, age 65-74 & 20.3 & 18.9 & 19.9 & 20.1 \\
\hline & $(0.2)$ & $(0.2)$ & $(0.2)$ & $(0.3)$ \\
\hline Life Expectancy, age 75-84 & 13.0 & 12.5 & 13.0 & 13.0 \\
\hline & $(0.2)$ & $(0.1)$ & $(0.2)$ & $(0.2)$ \\
\hline Life Expectancy, age 85+ & 7.3 & 7.4 & 7.5 & 7.4 \\
\hline & $(0.1)$ & $(0.1)$ & $(0.2)$ & $(0.2)$ \\
\hline
\end{tabular}




\begin{tabular}{|c|c|c|c|c|}
\hline \multirow[t]{2}{*}{ Atlanta zip code } & 11.4 & 15.1 & 0.0 & 7.1 \\
\hline & (2.3) & (3.9) & $(0.0)$ & $(2.4)$ \\
\hline \multirow[t]{2}{*}{ Baltimore zip code } & 8.9 & 14.9 & 0.0 & 2.4 \\
\hline & (2.1) & (3.9) & $(0.0)$ & $(1.4)$ \\
\hline \multirow[t]{2}{*}{ Chicago zip code } & 12.2 & 22.9 & 21.8 & 11.6 \\
\hline & (2.4) & (4.6) & (6.0) & $(3.0)$ \\
\hline \multirow[t]{2}{*}{ New York City zip code } & 39.5 & 41.6 & 55 & 58.4 \\
\hline & (3.6) & (5.4) & (7.2) & $(4.6)$ \\
\hline \multirow[t]{2}{*}{ San Diego zip code } & 25.3 & 0.0 & 23.2 & 19.4 \\
\hline & (3.2) & $(0.0)$ & (6.1) & (3.7) \\
\hline \multirow[t]{2}{*}{ St. Louis zip code } & 2.8 & 5.5 & 0.0 & 1.1 \\
\hline & (1.2) & (2.5) & $(0.0)$ & $(1.0)$ \\
\hline Number of ZIP Codes & 188 & 84 & 49 & 115 \\
\hline
\end{tabular}




\begin{tabular}{|c|c|c|c|c|c|c|c|c|c|c|}
\hline \multicolumn{11}{|c|}{ Table 3: COVID-19 Cases Per 10k Population } \\
\hline & \multicolumn{10}{|c|}{6 cities (Atlanta, Baltimore, Chicago, New York City, San Diego, St. Louis), N=436 ZIP codes } \\
\hline & (1) & $(2)$ & (3) & (4) & (5) & (6) & (7) & (8) & (9) & $(10)$ \\
\hline \multirow[t]{2}{*}{ \% Black } & $0.92^{* * *}$ & $0.94^{* * *}$ & $0.97^{* * *}$ & $0.86^{* * *}$ & $0.85^{* * *}$ & $0.54^{* *}$ & $0.65 * * *$ & $0.76^{* * *}$ & $0.72^{* * *}$ & $0.59 * * *$ \\
\hline & $(0.13)$ & (0.13) & (0.16) & (0.19) & $(0.21)$ & $(0.23)$ & $(0.21)$ & $(0.21)$ & $(0.22)$ & $(0.23)$ \\
\hline \multirow[t]{2}{*}{ \% Hispanic } & $2.06 * * *$ & $1.29 * * *$ & $1.67 * * *$ & $1.51 * * *$ & $1.53 * * *$ & $1.26 * * *$ & $1.42 * * *$ & $1.32 * * *$ & $1.29 * * *$ & $1.22 * * *$ \\
\hline & $(0.21)$ & $(0.23)$ & $(0.27)$ & $(0.38)$ & $(0.38)$ & $(0.38)$ & $(0.35)$ & $(0.35)$ & $(0.34)$ & $(0.33)$ \\
\hline \multirow[t]{3}{*}{$\operatorname{Adj} R^{2}$} & 0.76 & 0.81 & 0.85 & 0.85 & 0.85 & 0.86 & 0.87 & 0.88 & 0.88 & 0.88 \\
\hline & \multicolumn{10}{|c|}{2 cities (Chicago, New York City), N=235 ZIP codes } \\
\hline & (1) & (2) & (3) & (4) & (5) & (6) & (7) & (8) & (9) & $(10)$ \\
\hline \multirow[t]{2}{*}{ \% Black } & $1.24^{* * *}$ & $1.10 * * *$ & $1.45^{* * *}$ & $1.18^{* * *}$ & $0.91 * * *$ & $0.89 * *$ & $1.16^{* * *}$ & $1.32^{* * *}$ & $1.26^{* * *}$ & $1.26 * * *$ \\
\hline & $(0.19)$ & $(0.21)$ & $(0.22)$ & $(0.30)$ & $(0.34)$ & $(0.36)$ & $(0.35)$ & $(0.34)$ & $(0.28)$ & $(0.32)$ \\
\hline \multirow{2}{*}{ \% Hispanic } & $2.48 * * *$ & $1.47 * * *$ & $2.31 * * *$ & $1.81 * * *$ & $1.71 * * *$ & $1.65 * * *$ & $1.84^{* * *}$ & $1.76^{* * *}$ & $1.31 * * *$ & $1.29 * * *$ \\
\hline & $(0.26)$ & $(0.28)$ & $(0.32)$ & $(0.53)$ & $(0.54)$ & $(0.54)$ & $(0.54)$ & $(0.53)$ & $(0.35)$ & $(0.38)$ \\
\hline $\operatorname{Adj} R^{2}$ & 0.44 & 0.63 & 0.72 & 0.73 & 0.73 & 0.73 & 0.75 & 0.75 & 0.91 & 0.91 \\
\hline Demographics & No & Yes & Yes & Yes & Yes & Yes & Yes & Yes & Yes & Yes \\
\hline Housing & No & No & Yes & Yes & Yes & Yes & Yes & Yes & Yes & Yes \\
\hline Socioeconomic & No & No & No & Yes & Yes & Yes & Yes & Yes & Yes & Yes \\
\hline Opportunity Atlas & No & No & No & No & Yes & Yes & Yes & Yes & Yes & Yes \\
\hline Occupational & No & No & No & No & No & Yes & Yes & Yes & Yes & Yes \\
\hline Transportation & No & No & No & No & No & No & Yes & Yes & Yes & Yes \\
\hline SafeGraph & No & No & No & No & No & No & No & Yes & Yes & Yes \\
\hline Health access & No & No & No & No & No & No & No & No & Yes & Yes \\
\hline Population health & No & No & No & No & No & No & No & No & No & Yes \\
\hline \multicolumn{11}{|c|}{$\begin{array}{l}\text { Notes: All specifications include city fixed effects, "\% Other non-white", and a constant term. Unit of observation is ZIP code. Demographic variables include percentage in ZIP } \\
\text { code who are male, foreign born, or in age bins ( } 18-44,45-64,65-74,75+) \text {. Housing variables include density, percentage who are renters, percent of units vacant, percentage } \\
\text { who are in nursing homes, correctional facilities, college dorms, or military barracks ( } 2010 \text { Census), percent overcrowded (1.5+ per room), and percent with } 0 \text { or } 1 \text { bedroom } \\
\text { sizes. Socioeconomic variables include percent in education bins (dropout, high school, some college, bachelor's degree), Gini coefficient, percent in poverty bins (0-49\% FPL, } \\
50-74 \%, 75-99 \%, 100-149 \%, 150-199 \%) . \text { Opportunity Atlas variables include income mobility and male incarceration (Opportunity Atlas). Occupation variables include percent } \\
\text { of workers in service occupations, sales, farming, construction, production, or transport. Transportation variables include percent of workers of workers who use a car, } \\
\text { percent who use public transportation, and percent with long commuting times (60+ minutes). Safegraph variables include percent who on average remained at home all day } \\
\text { in each month from March-May } 2020 \text { (Safegraph). Health access variables include health professional shortage areas (HRSA; mental health, primary care), percent without } \\
\text { health insurance, and COVID-19 tests per capita (Chicago and New York City only). Population health variables include conditional life expectancy (CDC, ages } 65-74,75-84, \\
85+\text { ). All control variables obtained from } 2018 \text { ACS 5-year sample unless otherwise indicated. All regressions weighted by ZIP code population from } 2018 \text { ACS 5-year sample. } \\
\text { Heteroscedasticity-robust standard errors in parentheses. }\end{array}$} \\
\hline
\end{tabular}




\begin{tabular}{|c|c|c|c|c|c|c|c|c|c|c|c|}
\hline \multicolumn{12}{|c|}{ Table 4: COVID-19 Fatalities Per 1m Population } \\
\hline & \multicolumn{11}{|c|}{2 cities (Chicago, New York City), N=235 ZIP codes } \\
\hline & (1) & $(2)$ & (3) & $(4)$ & $(5)$ & $(6)$ & $(7)$ & $(8)$ & (9) & $(10)$ & $(11)$ \\
\hline \multirow[t]{2}{*}{ \% Black } & $14.3^{* * *}$ & $6.7^{* * *}$ & $5.8^{* * *}$ & $3.9 * *$ & $7.3^{* *}$ & 2.7 & 4.6 & 2.0 & 3.6 & 1.6 & -0.1 \\
\hline & $(2.0)$ & $(2.0)$ & $(2.0)$ & $(2.2)$ & $(3.1)$ & $(4.0)$ & $(4.2)$ & $(4.2)$ & (4.) & (4.5) & $(4.5)$ \\
\hline \multirow[t]{2}{*}{ \% Hispanic } & $14.9 * * *$ & -0.4 & -0.4 & -4.4 & 3.8 & 1.4 & 2.6 & 0.9 & 1.2 & -0.1 & -0.5 \\
\hline & (2.6) & (2.9) & (2.7) & (2.7) & (3.8) & $(4.0)$ & (4.5) & $(4.2)$ & (4.3) & $(4.3)$ & $(4.3)$ \\
\hline $\operatorname{Adj} R^{2}$ & 0.43 & 0.61 & 0.69 & 0.79 & 0.81 & 0.81 & 0.83 & 0.84 & 0.84 & 0.84 & 0.84 \\
\hline Cases Per 100k Pop & No & Yes & Yes & Yes & Yes & Yes & Yes & Yes & Yes & Yes & Yes \\
\hline Demographics & No & No & Yes & Yes & Yes & Yes & Yes & Yes & Yes & Yes & Yes \\
\hline Housing & No & No & No & Yes & Yes & Yes & Yes & Yes & Yes & Yes & Yes \\
\hline Socioeconomic & No & No & No & No & Yes & Yes & Yes & Yes & Yes & Yes & Yes \\
\hline Opportunity Atlas & No & No & No & No & No & Yes & Yes & Yes & Yes & Yes & Yes \\
\hline Occupational & No & No & No & No & No & No & Yes & Yes & Yes & Yes & Yes \\
\hline Transportation & No & No & No & No & No & No & No & Yes & Yes & Yes & Yes \\
\hline SafeGraph & No & No & No & No & No & No & No & No & Yes & Yes & Yes \\
\hline Health access & No & No & No & No & No & No & No & No & No & Yes & Yes \\
\hline Population health & No & No & No & No & No & No & No & No & No & No & Yes \\
\hline \multicolumn{12}{|c|}{$\begin{array}{l}\text { Notes: All specifications include city fixed effects, "\% Other non-white", and a constant term. Unit of observation is ZIP code. Demographic variables include percentage in ZIP } \\
\text { code who are male, foreign born, or in age bins ( } 18-44,45-64,65-74,75+) \text {. Housing variables include density, percentage who are renters, percent of units vacant, percentage } \\
\text { who are in nursing homes, correctional facilities, college dorms, or military barracks ( } 2010 \text { Census), percent overcrowded (1.5+ per room), and percent with } 0 \text { or } 1 \text { bedroom } \\
\text { sizes. Socioeconomic variables include percent in education bins (dropout, high school, some college, bachelor's degree), Gini coefficient, percent in poverty bins (0-49\% FPL, } \\
50-74 \%, 75-99 \%, 100-149 \%, 150-199 \%) \text {. Opportunity Atlas variables include income mobility and male incarceration (Opportunity Atlas). Occupation variables include percent } \\
\text { of workers in service occupations, sales, farming, construction, production, or transport. Transportation variables include percent of workers of workers who use a car, } \\
\text { percent who use public transportation, and percent with long commuting times (60+ minutes). Safegraph variables include percent who on average remained at home all day } \\
\text { in each month from March-May } 2020 \text { (Safegraph). Health access variables include health professional shortage areas (HRSA; mental health, primary care), percent without } \\
\text { health insurance, and COVID-19 tests per capita (Chicago and New York City only). Population health variables include conditional life expectancy (CDC, ages } 65-74,75-84, \\
85+\text { ). All control variables obtained from } 2018 \text { ACS 5-year sample unless otherwise indicated. All regressions weighted by ZIP code population from } 2018 \text { ACS 5-year sample. } \\
\text { Heteroscedasticity-robust standard errors in parentheses. }\end{array}$} \\
\hline
\end{tabular}




\begin{tabular}{|c|c|c|c|c|}
\hline \multicolumn{5}{|c|}{ Table 5: Accounting for change in coefficients } \\
\hline \multirow[b]{2}{*}{ Coefficient } & & $(1)$ & $(2)$ & (3) \\
\hline & & COVID-19 Cases & COVID-19 Cases & COVID-19 Fatalities \\
\hline \multirow[t]{12}{*}{$\%$ Black } & Baseline Coefficient & $0.92 * * *(0.13)$ & $1.24 * * *(0.19)$ & $14.3^{* * *}(2.0)$ \\
\hline & Explained Difference & $0.33(0.24)$ & $-0.03(0.36)$ & $14.4 * * *(4.9)$ \\
\hline & Cases Per 100k Pop & N/A & N/A & $9.3^{* * *}(1.9)$ \\
\hline & Demographics & $-0.06(0.09)$ & $0.09(0.13)$ & $1.3(1.9)$ \\
\hline & Housing & $-0.14(0.12)$ & $-0.25 * *(0.11)$ & $2.6(1.8)$ \\
\hline & Socioeconomic & $-0.23(0.34)$ & $-0.71 *(0.40)$ & $-15.0 * *(6.2)$ \\
\hline & Opportunity Atlas & $0.39 * * *(0.13)$ & $0.09(0.11)$ & $1.1(1.9)$ \\
\hline & Occupational & $0.32(0.32)$ & $0.21(0.33)$ & $9.4 *(5.4)$ \\
\hline & Transportation & $0.09(0.13)$ & $0.21(0.14)$ & $0.5(2.0)$ \\
\hline & SafeGraph & $0.07(0.05)$ & $0.12 * *(0.05)$ & $0.9(0.7)$ \\
\hline & Health access & $0.04(0.09)$ & $0.34 * *(0.15)$ & $1.2(1.3)$ \\
\hline & Population health & $-0.16(0.10)$ & $-0.13(0.12)$ & $3.0 *(1.6)$ \\
\hline \multirow[t]{12}{*}{ \% Hispanic } & Baseline Coefficient & $2.06 * * *(0.21)$ & $2.48 * * *(0.26)$ & $14.9 * * *(2.6)$ \\
\hline & Explained Difference & $0.84 * *(0.36)$ & $1.19 * *(0.46)$ & $15.4 * * *(4.9)$ \\
\hline & Cases Per 100k Pop & N/A & N/A & $18.7 * * *(3.4)$ \\
\hline & Demographics & $0.55 * * *(0.18)$ & $0.38 *(0.19)$ & $-2.4(2.9)$ \\
\hline & Housing & $-0.32(0.25)$ & $-0.37 *(0.20)$ & $1.7(3.4)$ \\
\hline & Socioeconomic & $-0.09(0.58)$ & $-0.40(0.59)$ & $-19.1 * *(9.2)$ \\
\hline & Opportunity Atlas & $0.17 * * *(0.06)$ & $0.05(0.05)$ & $0.6(0.7)$ \\
\hline & Occupational & $0.25(0.54)$ & $0.29(0.54)$ & $9.5(9.1)$ \\
\hline & Transportation & $0.10(0.22)$ & $0.09(0.14)$ & $0.7(1.5)$ \\
\hline & SafeGraph & $0.25 * * *(0.10)$ & $0.25 * * *(0.09)$ & $1.5(1.3)$ \\
\hline & Health access & $0.10(0.22)$ & $1.00 * * *(0.26)$ & $2.2(3.3)$ \\
\hline & Population health & $-0.10(0.07)$ & $-0.09(0.0)$ & $2.0 *(1.2)$ \\
\hline
\end{tabular}




\begin{tabular}{|c|c|c|c|c|c|c|c|c|c|c|}
\hline \multicolumn{11}{|c|}{ Table 6: COVID-19 Cases Per 10k Population (Highly segregated ZIP codes) } \\
\hline & \multicolumn{10}{|c|}{6 cities (Atlanta, Baltimore, Chicago, New York City, San Diego, St. Louis), N=327 ZIP codes } \\
\hline & (1) & (2) & (3) & (4) & (5) & (6) & (7) & (8) & (9) & $(10)$ \\
\hline \multirow[t]{2}{*}{$\%$ Black } & $0.92 * * *$ & $0.85^{* * *}$ & $0.88 * * *$ & $0.87 * * *$ & $0.91 * * *$ & $0.65^{* * *}$ & $0.72 * * *$ & $0.81 * * *$ & $0.78 * * *$ & $0.68 * * *$ \\
\hline & $(0.14)$ & $(0.14)$ & (0.19) & $(0.21)$ & $(0.23)$ & $(0.24)$ & $(0.23)$ & $(0.22)$ & $(0.23)$ & $(0.24)$ \\
\hline \multirow[t]{2}{*}{ \% Hispanic } & $2.18^{* * *}$ & $1.17^{* * *}$ & $1.44^{* * *}$ & $1.07 * *$ & $1.08 * *$ & $0.88^{* *}$ & $1.06 * * *$ & $0.97 * * *$ & $0.95 * *$ & $0.92 * *$ \\
\hline & $(0.23)$ & $(0.24)$ & (0.29) & $(0.45)$ & $(0.45)$ & $(0.40)$ & $(0.38)$ & $(0.37)$ & $(0.38)$ & $(0.37)$ \\
\hline $\operatorname{Adj} R^{2}$ & 0.76 & 0.83 & 0.86 & 0.87 & 0.87 & 0.88 & 0.89 & 0.89 & 0.89 & 0.89 \\
\hline Demographics & No & Yes & Yes & Yes & Yes & Yes & Yes & Yes & Yes & Yes \\
\hline Housing & No & No & Yes & Yes & Yes & Yes & Yes & Yes & Yes & Yes \\
\hline Socioeconomic & No & No & No & Yes & Yes & Yes & Yes & Yes & Yes & Yes \\
\hline Opportunity Atlas & No & No & No & No & Yes & Yes & Yes & Yes & Yes & Yes \\
\hline Occupational & No & No & No & No & No & Yes & Yes & Yes & Yes & Yes \\
\hline Transportation & No & No & No & No & No & No & Yes & Yes & Yes & Yes \\
\hline SafeGraph & No & No & No & No & No & No & No & Yes & Yes & Yes \\
\hline Health access & No & No & No & No & No & No & No & No & Yes & Yes \\
\hline Population health & No & No & No & No & No & No & No & No & No & Yes \\
\hline \multicolumn{11}{|c|}{$\begin{array}{l}\text { Notes: All specifications include city fixed effects, "\% Other non-white", and a constant term. Unit of observation is ZIP code. Demographic variables include percentage in ZIP } \\
\text { code who are male, foreign born, or in age bins ( } 18-44,45-64,65-74,75+) \text {. Housing variables include density, percentage who are renters, percent of units vacant, percentage } \\
\text { who are in nursing homes, correctional facilities, college dorms, or military barracks ( } 2010 \text { Census), percent overcrowded ( } 1.5+\text { per room), and percent with } 0 \text { or } 1 \text { bedroom } \\
\text { sizes. Socioeconomic variables include percent in education bins (dropout, high school, some college, bachelor's degree), Gini coefficient, percent in poverty bins (0-49\% FPL, } \\
50-74 \%, 75-99 \%, 100-149 \%, 150-199 \%) . \text { Opportunity Atlas variables include income mobility and male incarceration (Opportunity Atlas). Occupation variables include percent } \\
\text { of workers in service occupations, sales, farming, construction, production, or transport. Transportation variables include percent of workers of workers who use a car, } \\
\text { percent who use public transportation, and percent with long commuting times (60+ minutes). Safegraph variables include percent who on average remained at home all day } \\
\text { in each month from March-May } 2020 \text { (Safegraph). Health access variables include health professional shortage areas (HRSA; mental health, primary care), percent without } \\
\text { health insurance, and COVID-19 tests per capita (Chicago and New York City only). Population health variables include conditional life expectancy (CDC, ages } 65-74,75-84, \\
85+\text { ). All control variables obtained from } 2018 \text { ACS 5-year sample unless otherwise indicated. All regressions weighted by ZIP code population from } 2018 \text { ACS 5-year sample. } \\
\text { Heteroscedasticity-robust standard errors in parentheses. }\end{array}$} \\
\hline
\end{tabular}




\begin{tabular}{|c|c|c|c|c|c|c|c|c|c|c|c|c|}
\hline \multicolumn{13}{|c|}{ Table 7: COVID-19 Cases Per 10k Population (Leave one city out) } \\
\hline & (1) & (2) & (3) & (4) & (5) & (6) & (7) & (8) & (9) & (10) & (11) & (12) \\
\hline \% Black & $\begin{array}{c}0.98^{* * *} \\
(0.15)\end{array}$ & $\begin{array}{c}0.64^{* * * *} \\
(0.25)\end{array}$ & $\begin{array}{c}0.98^{* * *} \\
(0.14)\end{array}$ & $\begin{array}{c}0.68 * * * \\
(0.26)\end{array}$ & $\begin{array}{c}0.90 * * * \\
(0.16)\end{array}$ & $\begin{array}{c}0.46^{* *} \\
(0.23)\end{array}$ & $\begin{array}{c}0.64^{* * *} \\
(0.12)\end{array}$ & $\begin{array}{c}0.45 \\
(0.28)\end{array}$ & $\begin{array}{c}1.02^{* * *} \\
(0.15)\end{array}$ & $\begin{array}{c}0.84^{* * *} \\
(0.25)\end{array}$ & $\begin{array}{c}0.95 * * * \\
(0.14)\end{array}$ & $\begin{array}{c}0.65^{* * * *} \\
(0.23)\end{array}$ \\
\hline \% Hispanic & $\begin{array}{c}2.10^{* * *} \\
(0.22)\end{array}$ & $\begin{array}{c}1.24^{* * *} \\
(0.34)\end{array}$ & $\begin{array}{c}2.06^{* * *} \\
(0.22)\end{array}$ & $\begin{array}{c}1.31^{* * *} \\
(0.37)\end{array}$ & $\begin{array}{c}1.65 * * * \\
(0.23)\end{array}$ & $\begin{array}{c}1.17^{* * *} \\
(0.36)\end{array}$ & $\begin{array}{c}2.05^{* * *} \\
(0.27)\end{array}$ & $\begin{array}{c}1.09 * * \\
(0.46)\end{array}$ & $\begin{array}{c}2.39 * * * \\
(0.26)\end{array}$ & $\begin{array}{c}1.51^{* * *} \\
(0.38)\end{array}$ & $\begin{array}{c}2.06 * * * \\
(0.21)\end{array}$ & $\begin{array}{c}1.22 * * * \\
(0.33)\end{array}$ \\
\hline $\operatorname{Adj} R^{2}$ & 0.73 & 0.87 & 0.76 & 0.88 & 0.78 & 0.90 & 0.78 & 0.85 & 0.67 & 0.85 & 0.75 & 0.88 \\
\hline Full controls & \multirow{2}{*}{\multicolumn{2}{|c|}{ Atlanta }} & & Yes & & Yes & No & Yes & No & $\mathrm{Ye}$ & No & Yes \\
\hline Leave out & & & Balt & ore & \multicolumn{2}{|c|}{ Chicago } & New $Y$ & City & \multicolumn{2}{|c|}{ San Diego } & \multicolumn{2}{|c|}{ St. Louis } \\
\hline \multicolumn{13}{|c|}{$\begin{array}{l}\text { Notes: All specifications include city fixed effects, "\% Other non-white", and a constant term. Unit of observation is ZIP code. Demographic variables include percentage in ZIP } \\
\text { code who are male, foreign born, or in age bins (18-44, 45-64, } 65-74,75+) \text {. Housing variables include density, percentage who are renters, percent of units vacant, percentage } \\
\text { who are in nursing homes, correctional facilities, college dorms, or military barracks ( } 2010 \text { Census), percent overcrowded (1.5+ per room), and percent with } 0 \text { or } 1 \text { bedroom } \\
\text { sizes. Socioeconomic variables include percent in education bins (dropout, high school, some college, bachelor's degree), Gini coefficient, percent in poverty bins (0-49\% FPL, } \\
50-74 \%, 75-99 \%, 100-149 \%, 150-199 \%) \text {. Opportunity Atlas variables include income mobility and male incarceration (Opportunity Atlas). Occupation variables include percent } \\
\text { of workers in service occupations, sales, farming, construction, production, or transport. Transportation variables include percent of workers of workers who use a car, } \\
\text { percent who use public transportation, and percent with long commuting times (60+ minutes). Safegraph variables include percent who on average remained at home all day } \\
\text { in each month from March-May } 2020 \text { (Safegraph). Health access variables include health professional shortage areas (HRSA; mental health, primary care), percent without } \\
\text { health insurance, and COVID-19 tests per capita (Chicago and New York City only). Population health variables include conditional life expectancy (CDC, ages } 65-74,75-84 \text {, } \\
\text { 85+). All control variables obtained from } 2018 \text { ACS 5-year sample unless otherwise indicated. All regressions weighted by ZIP code population from } 2018 \text { ACS 5-year sample. } \\
\text { Heteroscedasticity-robust standard errors in parentheses. }\end{array}$} \\
\hline
\end{tabular}




\begin{tabular}{|c|c|c|c|c|c|c|}
\hline \multicolumn{7}{|c|}{ Appendix Table 1: Base and Full Models for Main Specifications } \\
\hline & \multicolumn{2}{|c|}{$\begin{array}{c}\text { Confirmed COVID-19 case per 10k pop } \\
6 \text { Cities }\end{array}$} & \multicolumn{2}{|c|}{$\begin{array}{l}\text { Confirmed COVID-19 case per 10k pop } \\
2 \text { Cities }\end{array}$} & \multicolumn{2}{|c|}{$\begin{array}{l}\text { COVID-19 fatalities per } 1 \mathrm{~m} \text { pop } \\
2 \text { Cities }\end{array}$} \\
\hline & Base & Full & Base & Full & Base & Full \\
\hline \% Black & $\begin{array}{c}0.923 * * * \\
(0.134)\end{array}$ & $\begin{array}{c}0.593 * * * \\
(0.226)\end{array}$ & $\begin{array}{c}1.236 * * * \\
(0.191)\end{array}$ & $\begin{array}{c}1.262^{* * *} \\
(0.318)\end{array}$ & $\begin{array}{l}14.3^{* * * *} \\
(2)\end{array}$ & $\begin{array}{l}-0.1 \\
(4.5)\end{array}$ \\
\hline$\%$ Hispanic & $\begin{array}{c}2.057^{* * *} \\
(0.213)\end{array}$ & $\begin{array}{c}1.218^{* * *} \\
(0.332)\end{array}$ & $\begin{array}{c}2.484 * * * \\
(0.263)\end{array}$ & $\begin{array}{l}1.29 * * * \\
(0.375)\end{array}$ & $\begin{array}{c}14.9 * * * \\
(2.6)\end{array}$ & $\begin{array}{l}-0.4 \\
(4.3)\end{array}$ \\
\hline$\%$ Other & $\begin{array}{l}0.511^{*} \\
(0.305)\end{array}$ & $\begin{array}{c}-0.987^{* *} \\
(0.415)\end{array}$ & $\begin{array}{c}0.886^{* *} \\
(0.409)\end{array}$ & $\begin{array}{l}-0.403 \\
(0.391)\end{array}$ & $\begin{array}{c}13.5^{* *} \\
(5.6)\end{array}$ & $\begin{array}{l}2.7 \\
(5)\end{array}$ \\
\hline Atlanta zip code & $\begin{array}{c}-175.251^{* * *} \\
(8.597)\end{array}$ & $\begin{array}{c}-264.171^{* * *} \\
(26.535)\end{array}$ & & & & \\
\hline Baltimore zip code & $\begin{array}{c}-108.232^{* * *} \\
(10.873)\end{array}$ & $\begin{array}{c}-180.516^{* * *} \\
(19.534)\end{array}$ & & & & \\
\hline Chicago zip code & $\begin{array}{c}-63.606 * * * \\
(10.514)\end{array}$ & $\begin{array}{c}-122.915^{* * *} \\
(15.539)\end{array}$ & $\begin{array}{c}-62.821^{* * *} \\
(10.139)\end{array}$ & $\begin{array}{c}-52.887 * * * \\
(19.687)\end{array}$ & $\begin{array}{c}-1191.6^{* * *} \\
(98.2)\end{array}$ & $\begin{array}{l}-127.2 \\
(238.7)\end{array}$ \\
\hline San Diego zip code & $\begin{array}{c}-200.835^{* * *} \\
(7.221)\end{array}$ & $\begin{array}{c}-238.392 * * * \\
(22.822)\end{array}$ & & & & \\
\hline St. Louis zip code & $\begin{array}{c}-150.886^{* * *} \\
(13.499)\end{array}$ & $\begin{array}{c}-231.067^{* * *} \\
(28.413)\end{array}$ & & & & \\
\hline Confirmed COVID-19 case per $10 \mathrm{k}$ pop & & & & & & $\begin{array}{l}7.5 * * * \\
(1)\end{array}$ \\
\hline$\%$ Male & & $\begin{array}{c}4.006^{* * *} \\
(1.338)\end{array}$ & & $\begin{array}{l}-0.165 \\
(1.167)\end{array}$ & & $\begin{array}{c}-18 \\
(24.5)\end{array}$ \\
\hline$\%$ Foreign-born & & $\begin{array}{l}1.164^{* *} \\
(0.452)\end{array}$ & & $\begin{array}{l}0.757^{*} \\
(0.402)\end{array}$ & & $\begin{array}{c}4 \\
(5.6)\end{array}$ \\
\hline$\%$ Age $18-44$ & & $\begin{array}{l}-1.464^{*} \\
(0.756)\end{array}$ & & $\begin{array}{l}-0.313 \\
(0.915)\end{array}$ & & $\begin{array}{l}-17.2 \\
(13.2)\end{array}$ \\
\hline$\%$ Age $45-64$ & & $\begin{array}{l}-2.45^{* *} \\
(1.097)\end{array}$ & & $\begin{array}{l}-1.181 \\
(1.204)\end{array}$ & & $\begin{array}{l}-19 \\
(21.1)\end{array}$ \\
\hline$\%$ Age $65-74$ & & $\begin{array}{l}0.812 \\
(2.074)\end{array}$ & & $\begin{array}{l}0.363 \\
(2.553)\end{array}$ & & $\begin{array}{c}32.9 \\
(31.9)\end{array}$ \\
\hline$\%$ Age $75+$ & & $\begin{array}{l}-0.953 \\
(2.077)\end{array}$ & & $\begin{array}{l}-2.912 \\
(2.229)\end{array}$ & & $\begin{array}{c}60.7 * * \\
(29.1)\end{array}$ \\
\hline Density & & $\begin{array}{c}0 \\
(0)\end{array}$ & & $\begin{array}{c}0 \\
(0)\end{array}$ & & $\begin{array}{c}0 \\
(0)\end{array}$ \\
\hline$\%$ Renter & & $\begin{array}{c}-0.39 \\
(0.423)\end{array}$ & & $\begin{array}{l}-0.559 \\
(0.448)\end{array}$ & & $\begin{array}{c}4.3 \\
(7.1)\end{array}$ \\
\hline$\%$ Vacant & & $\begin{array}{l}1.052^{*} \\
(0.628)\end{array}$ & & $\begin{array}{l}-1.214 \\
(0.809)\end{array}$ & & $\begin{array}{c}7.1 \\
(8.9)\end{array}$ \\
\hline
\end{tabular}




\begin{tabular}{|c|c|c|c|}
\hline \% Correctional group quarters & $\begin{array}{l}0.705 \\
1.377)\end{array}$ & $\begin{array}{c}2.396 * * * \\
(0743)\end{array}$ & $\begin{array}{l}-27.7^{* *} \\
(13.3)\end{array}$ \\
\hline$\%$ Nursing home group quarters & $\begin{array}{c}16.452^{* * *} \\
(4.956)\end{array}$ & $6.054^{* *}$ & $\begin{array}{c}278.9 * * * \\
(100.2)\end{array}$ \\
\hline$\%$ College group quarters & $\begin{array}{c}(4.956) \\
2.686 * * *\end{array}$ & $\begin{array}{c}(2.827) \\
1.53\end{array}$ & 23.4 \\
\hline & $(0.853)$ & $(0.962)$ & (16.7) \\
\hline \% Military group quarters & $\begin{array}{l}-0.577 \\
(0.856)\end{array}$ & $\begin{array}{c}274.535^{* *} \\
(121.418)\end{array}$ & $\begin{array}{c}158.8 \\
(2996.4)\end{array}$ \\
\hline$\% 1.5+$ Occupants per bedroom & $\begin{array}{c}1.54 \\
(2.865)\end{array}$ & $\begin{array}{l}-1.542 \\
(1.66)\end{array}$ & $\begin{array}{c}17.4 \\
(23.4)\end{array}$ \\
\hline$\%$ Unit is 0 or 1 bedroom & $\begin{array}{c}1.193 * * * \\
(0.415)\end{array}$ & $\begin{array}{c}0.865^{* *} \\
(0.34)\end{array}$ & $\begin{array}{l}-7.2 \\
(5.1)\end{array}$ \\
\hline$\%$ HS Dropout & $\begin{array}{l}-0.061 \\
(1.384)\end{array}$ & $\begin{array}{c}0.091 \\
(1.284)\end{array}$ & $\begin{array}{c}-3.4 \\
(16.7)\end{array}$ \\
\hline \% HS Graduate/GED & $\begin{array}{l}1.997^{* *} \\
(0.997)\end{array}$ & $\begin{array}{c}0.71 \\
(0.86)\end{array}$ & $\begin{array}{c}9.5 \\
(13.3)\end{array}$ \\
\hline$\%$ Some College & $\begin{array}{c}-2.392^{* *} \\
(1.004)\end{array}$ & $\begin{array}{c}-3.827^{* * *} \\
(1.101)\end{array}$ & $\begin{array}{c}-7.5 \\
(16.6)\end{array}$ \\
\hline \% Bachelor's degree & $\begin{array}{c}1.148 \\
(1.024)\end{array}$ & $\begin{array}{c}1.03 \\
(1.208)\end{array}$ & $\begin{array}{c}49.2^{* * * *} \\
(17.5)\end{array}$ \\
\hline Gini coefficient & $\begin{array}{l}-135.128 \\
(90.609)\end{array}$ & $\begin{array}{c}27.099 \\
(85.101)\end{array}$ & $\begin{array}{c}2261.5 \\
(1523.7)\end{array}$ \\
\hline \% 0-49 FPL & $\begin{array}{c}1.003 \\
(1.205)\end{array}$ & $\begin{array}{c}1.075 \\
(1.217)\end{array}$ & $\begin{array}{l}-13.9 \\
(18.1)\end{array}$ \\
\hline \% 50-74 FPL & $\begin{array}{c}1.588 \\
(2.075)\end{array}$ & $\begin{array}{l}-0.391 \\
(2.012)\end{array}$ & $\begin{array}{c}-62.3^{* *} \\
(29.9)\end{array}$ \\
\hline \% 75-99 FPL & $\begin{array}{l}-0.952 \\
(1.776)\end{array}$ & $\begin{array}{c}0.127 \\
(1.641)\end{array}$ & $\begin{array}{c}38.7 \\
(26.8)\end{array}$ \\
\hline \% 100-149 FPL & $\begin{array}{l}-0.176 \\
(1.569)\end{array}$ & $\begin{array}{c}-0.46 \\
(1.456)\end{array}$ & $\begin{array}{c}10.5 \\
(27.8)\end{array}$ \\
\hline \% 150-199 FPL & $\begin{array}{l}-1.166 \\
(1.552)\end{array}$ & $\begin{array}{c}0.25 \\
(1.521)\end{array}$ & $\begin{array}{c}3.9 \\
(24.6)\end{array}$ \\
\hline Income mobility & $\begin{array}{c}-199.703^{* * *} \\
(54.695)\end{array}$ & $\begin{array}{l}-69.522 \\
(74.58)\end{array}$ & $\begin{array}{c}-915.1 \\
(1114.3)\end{array}$ \\
\hline Male incarceration & $\begin{array}{c}116.042 \\
(121.102)\end{array}$ & $\begin{array}{c}-18.72 \\
(149.98)\end{array}$ & $\begin{array}{c}-340.2 \\
(1867.8)\end{array}$ \\
\hline \% Service & $\begin{array}{c}0.588 \\
(1.071)\end{array}$ & $\begin{array}{l}-0.655 \\
(0.983)\end{array}$ & $\begin{array}{c}37.3^{* *} \\
(16.7)\end{array}$ \\
\hline \% Sales Occupation & $\begin{array}{c}1.038 \\
(1.061)\end{array}$ & $\begin{array}{c}2.468^{* *} \\
(1.146)\end{array}$ & $\begin{array}{l}7.2 \\
(17)\end{array}$ \\
\hline \% Farming & $\begin{array}{c}-18.273^{* * *} \\
(6.386)\end{array}$ & $\begin{array}{l}-19.859 \\
(21.675)\end{array}$ & $\begin{array}{c}228.5 \\
(470.4)\end{array}$ \\
\hline
\end{tabular}




\begin{tabular}{|c|c|c|c|c|c|c|}
\hline$\%$ Construction & & $\begin{array}{l}-2.91^{*} \\
(1.517)\end{array}$ & & $\begin{array}{c}0.973 \\
(1.594)\end{array}$ & & $\begin{array}{c}7.9 \\
(27.1)\end{array}$ \\
\hline \% Production & & $\begin{array}{c}2.855 \\
(3.301)\end{array}$ & & $\begin{array}{c}1.551 \\
(2.702)\end{array}$ & & $\begin{array}{l}-64.2^{*} \\
(34.3)\end{array}$ \\
\hline \% Transport & & $\begin{array}{c}1.645 \\
(1.662)\end{array}$ & & $\begin{array}{l}2.592^{* *} \\
(1.173)\end{array}$ & & $\begin{array}{c}4.2 \\
(18.9)\end{array}$ \\
\hline \% Travel by car & & $\begin{array}{c}0.988^{* *} \\
(0.49)\end{array}$ & & $\begin{array}{c}0.983 \\
(0.601)\end{array}$ & & $\begin{array}{l}-10.6 \\
(8.9)\end{array}$ \\
\hline$\%$ Travel by public transit & & $\begin{array}{c}-1.304 * * * \\
(0.484)\end{array}$ & & $\begin{array}{c}-0.39 \\
(0.388)\end{array}$ & & $\begin{array}{l}-0.5 \\
(6.3)\end{array}$ \\
\hline$\% 60+$ minute commute & & $\begin{array}{c}1.262^{* *} \\
(0.503)\end{array}$ & & $\begin{array}{c}0.735 \\
(0.483)\end{array}$ & & $\begin{array}{c}7.5 \\
(7.1)\end{array}$ \\
\hline$\%$ Home all day, 3/2020 & & $\begin{array}{l}151.357 \\
(125.94)\end{array}$ & & $\begin{array}{c}91.833 \\
(114.989)\end{array}$ & & $\begin{array}{c}331.7 \\
(1513.7)\end{array}$ \\
\hline$\%$ Home all day, 4/2020 & & $\begin{array}{c}300.218^{* * *} \\
(95.738)\end{array}$ & & $\begin{array}{c}191.483^{* *} \\
(92.184)\end{array}$ & & $\begin{array}{c}2052.3 \\
(1289.9)\end{array}$ \\
\hline$\%$ Home all day, 5/2020 & & $\begin{array}{c}-325.512 * * \\
(146.591)\end{array}$ & & $\begin{array}{l}-110.497 \\
(117.307)\end{array}$ & & $\begin{array}{l}-2551^{*} \\
(1536)\end{array}$ \\
\hline Mental health HPSA & & $\begin{array}{c}27.891 \\
(18.825)\end{array}$ & & $\begin{array}{c}3.732 \\
(14.132)\end{array}$ & & $\begin{array}{l}-86.5 \\
(158)\end{array}$ \\
\hline Primary care HPSA & & $\begin{array}{c}-34.379 * * \\
(14.534)\end{array}$ & & $\begin{array}{l}-14.927 \\
(20.405)\end{array}$ & & $\begin{array}{c}704.6 * * * \\
(175.1)\end{array}$ \\
\hline$\%$ Uninsured & & $\begin{array}{c}0.262 \\
(1.306)\end{array}$ & & $\begin{array}{c}3.397^{* * *} \\
(1.17)\end{array}$ & & $\begin{array}{l}21.9 \\
(19.1)\end{array}$ \\
\hline COVID-19 tests per $10 \mathrm{k}$ pop & & & & $\begin{array}{c}0.223 * * * \\
(0.023)\end{array}$ & & $\begin{array}{c}-0.6^{* *} \\
(0.3)\end{array}$ \\
\hline Life Expectancy, age 65-74 & & $\begin{array}{c}7.129 \\
(6.275)\end{array}$ & & $\begin{array}{c}8.421 \\
(8.349)\end{array}$ & & $\begin{array}{l}-180.6 * \\
(100.6)\end{array}$ \\
\hline Life Expectancy, age 75-84 & & $\begin{array}{c}0.575 \\
(8.211)\end{array}$ & & $\begin{array}{l}-6.116 \\
(11.206)\end{array}$ & & $\begin{array}{c}121.7 \\
(119.3)\end{array}$ \\
\hline Life Expectancy, age 85+ & & $\begin{array}{l}-3.781 \\
(3.658)\end{array}$ & & $\begin{array}{l}0.23 \\
(4.2)\end{array}$ & & $\begin{array}{c}45.5 \\
(57.8)\end{array}$ \\
\hline Life expectancy missing & & $\begin{array}{c}58.425 \\
(65.566)\end{array}$ & & $\begin{array}{c}62.816 \\
(72.579)\end{array}$ & & $\begin{array}{l}-1693.1 \\
(1209.2)\end{array}$ \\
\hline Constant term & $\begin{array}{c}145.318^{* * *} \\
(12.63)\end{array}$ & $\begin{array}{c}-27.46 \\
(129.995)\end{array}$ & $\begin{array}{c}119.721^{* * *} \\
(16.532)\end{array}$ & $\begin{array}{c}-217.922 \\
(141.339)\end{array}$ & $\begin{array}{c}1047.4^{* * *} \\
(180.7)\end{array}$ & $\begin{array}{c}798.8 \\
(2703.6)\end{array}$ \\
\hline
\end{tabular}

